\title{
Interferon beta induces apoptosis in nasopharyngeal carcinoma cells via the TRAIL-signaling pathway
}

\author{
Anna Makowska ${ }^{1}$, Lora Wahab ${ }^{1}$, Till Braunschweig ${ }^{2}$, Nikiforos-Ioannis Kapetanakis ${ }^{3}$, \\ Christian Vokuhl', Bernd Denecke ${ }^{5}$, Lian Shen ${ }^{1}$, Pierre Busson ${ }^{3}$ and Udo Kontny ${ }^{1}$ \\ ${ }^{1}$ Division of Pediatric Hematology, Oncology and Stem Cell Transplantation, Medical Faculty, RWTH Aachen University, \\ Aachen, Germany \\ ${ }^{2}$ Institute of Pathology, Medical Faculty, RWTH Aachen University, Aachen, Germany \\ ${ }^{3}$ CNRS UMR 8126, Gustave Roussy and Université Paris-Sud/Paris-Saclay, Villejuif, France \\ ${ }^{4}$ Institute of Pathology, Kiel Pediatric Tumor Registry, Christian-Albrechts-University, Kiel, Germany \\ ${ }^{5}$ IZKF, Medical Faculty, RWTH Aachen University, Aachen, Germany
}

Correspondence to: Udo Kontny, email: ukontny@ukaachen.de

Keywords: nasopharyngeal carcinoma; interferon beta; TRAIL; apoptosis; siRNA

Received: June 08, 2017 Accepted: February 02, 2018 Epub: February 12, 2018 Published: March 06, 2018

Copyright: Makowska et al. This is an open-access article distributed under the terms of the Creative Commons Attribution License 3.0 (CC BY 3.0), which permits unrestricted use, distribution, and reproduction in any medium, provided the original author and source are credited.

\section{ABSTRACT}

The combination of neoadjuvant chemotherapy, radiochemotherapy, and maintenance therapy with interferon beta (IFN $\beta$ ) has led to superior results in the treatment of children and adolescents with nasopharyngeal carcinoma (NPC). However, nothing is known about the mechanism of the antitumor activity of IFN $\beta$ in NPC. Here, we investigate the role of IFN $\beta$ on apoptosis in NPC cells. Six NPC cell lines, one patient-derived NPC xenograft (PDX) and one SV40-transformed nasoepithelial cell line were used. Induction of apoptosis by IFN $\beta$ was measured by flow cytometric analysis of subG1-DNA-content, Hoechst 33258 staining and activation of caspase-3. Dissection of death ligand signaling pathways included measuring surface expression of its components by flow cytometry, activation by death ligands and neutralization with specific antibodies and siRNA. IFN $\beta$ induced apoptosis at concentrations achievable in humans in five of six NPC cell lines and in PDX cells but not in nasoepithelial cells. Inhibition of caspases-3 and -8 abrogated this effect suggesting IFN $\beta$ promoted apoptosis through the extrinsic pathway. IFN $\beta$ induced surface expression of TRAIL and TRAIL-R2 and the addition of an anti-TRAIL-antibody or transfection with TRAIL-siRNA blocked IFN $\beta$-induced apoptosis. No induction of TRAIL-expression was noted in the IFN $\beta$-resistant cell line. In conclusion, IFN $\beta$ leads to apoptosis in NPC cells in an autocrine way via the induction of TRAIL expression and subsequent activation of the TRAIL-signaling pathway. The mechanism described could at least partly explain the clinical benefit of IFN $\beta$ in the treatment of NPC. Further studies in a mouse-xenograft model are warranted to substantiate this effect in vivo.

\section{INTRODUCTION}

Nasopharyngeal carcinoma (NPC) is a malignant tumor arising from the surface epithelium of the posterior nasopharynx. Etiologic studies have demonstrated that
NPC follows a multistep process, in which Epstein-BarrVirus (EBV), ethnic background and environmental carcinogens seem to play an important role [1-2]. Most cases of NPC in children, adolescents and young adults present as advanced locoregional disease [3-7]. Survival 
chances for children with locoregional disease range between $80 \%$ and $90 \%$ and failures are mostly due to the development of distant relapses. In comparison, the survival chances for children with metastatic NPC at diagnosis are less than $10 \%$. Whereas simultaneous radiochemotherapy has been considered as standard therapy for adults with nasopharyngeal carcinoma [8], in children and adolescents, the addition of neoadjuvant chemotherapy has led to superior results [4-7]. The highest survival rates for localized NPC in children and adolescents, with overall survival rates and eventfree survival rates $>90 \%$, have been achieved with the GPOH-NPC-91 and -NPC-2003 studies, and this with lower radiation dosages compared with other prospective studies in pediatric NPC [5-6]. The GPOH concept is unique by the fact that in addition to neoadjuvant chemotherapy followed by radiochemotherapy, maintenance therapy with interferon- $\beta$ (IFN $\beta$ ) is given for 6 months [9]. IFN $\beta$ was integrated into the NPCGPOH treatment concept after a child with relapsing NPC and multiple intracerebral metastases went into complete remission being treated exclusively with IFN $\beta$ [10]. Evidence for a therapeutic benefit of IFN $\beta$ in NPC comes also from adults where patients treated with adjuvant IFN $\beta$ had a significant better outcome than patients being treated without IFN $\beta$ [11]. However, no biological studies have so far been conducted, exploring the effect of IFN $\beta$ in NPC cells.

IFN $\beta$ belongs as IFN $\alpha$ to the type I interferons which after binding to a common receptor induce through an intracellular signaling cascade the transcription of a number of genes involved in cell proliferation, apoptosis and immune recognition [12]. IFN $\beta$ is licensed for the treatment of multiple sclerosis [13]. In contrast, IFN $\alpha$ is used for treatment in various malignancies such as malignant melanoma, chronic myelogenous leukemia and renal cell cancer [14-16]. Its antitumor effect has been shown to rely directly on antiproliferative and proapoptotic effects in tumor cells, but also indirectly on orchestrating an effective anti-tumor immune response $[12,17]$. The way of induction of apoptosis by type I interferons in cancer cell lines has been shown to depend on the cellular background. Whereas in neuroblastoma cells, IFN $\beta$ induces apoptotic cell death through the intrinsic pathway by downregulation of phosphatidylinositol 3-kinase/ AKT signaling, cytochrome $\mathrm{C}$ release and activation of procaspase 9 [18], induction of apoptosis in melanoma and breast cancer cells is mediated via the extrinsic signaling pathway and dependent on the expression of the death ligand TRAIL [19-20].

In this study we have analyzed the effect of IFN $\beta$ on cell death in a panel of NPC cell lines and a nasoepithelial cell line to reveal possible biological mechanisms for its efficacy in the treatment of NPC. Since cell lines in general are genetically unstable, as in the NPC system documented by the loss of EBV during culture [21-22] and therefore might not reflect the biological behavior of originary tumor cells, we have included NPC cells freshly isolated from a patientderived xenograft in the analyses [23].

\section{RESULTS}

\section{IFN $\beta$ decreases the viability of NPC cells}

In a first experiment we investigated the effect of IFN $\beta$ on the viability of NPC cells using the WST- 8 reduction assay. All cell lines were treated with IFN $\beta$ at various concentrations $(0-5,000 \mathrm{U} / \mathrm{ml})$ for $24 \mathrm{~h}, 48 \mathrm{~h}$ or $72 \mathrm{~h}$. In humans, serum concentrations of up to $1,000 \mathrm{U} /$ $\mathrm{ml}$ can be achieved at therapeutic dosages, e.g. used for the treatment of multiple sclerosis [13, 24]. Incubation with IFN $\beta$ for $24 \mathrm{~h}$ led to a decrease in cell viability in two NPC cell lines (HONE-1 EBV, CNE-2) starting at a concentration of $500 \mathrm{U} / \mathrm{ml}$ and in C17-PDX cells at $1,000 \mathrm{U} / \mathrm{ml}$ (Figure 1). When cells were incubated with IFN $\beta$ for $48 \mathrm{~h}$, a significant decrease in the number of viable cells was noted in five out of six NPC cell lines and C17-PDX cells, starting at a concentration between 50 and $100 \mathrm{U} / \mathrm{ml}$. The percentage of viable cells further decreased after $72 \mathrm{~h}$ incubation with IFN $\beta$, ranging between 40 and $70 \%$ at a concentration of $1,000 \mathrm{U} / \mathrm{ml}$ in the five sensitive NPC cell lines and C17-PDX cells (HONE-1, HK1, TW01, C17-PDX: $p<0.001$; HONE-1 EBV, CNE-2: $p<0.01$ ). In contrast, no significant decrease in the number of viable cells was seen when cells of the nasopharyngeal epithelial cell line NP69 or NPC cell line C666-1 were treated with IFN $\beta$. Since the decrease in the number of viable cells by IFN $\beta$ could be either a consequence of cell death or reduction in cell proliferation, we next performed cell cycle analysis.

\section{IFN $\beta$ induces apoptosis in NPC cells}

NPC cells were treated with different concentration of IFN $\beta$ up to $72 \mathrm{~h}$ and cell cycle distribution was analyzed by flow cytometry of propidium iodide stained nuclei. Whereas no major effect on cell cycle distribution was noted in any of the cell lines studied, IFN $\beta$ induced a significant dose-dependent increase in apoptotic cells in five out of six NPC cell lines (Figure 2A and Supplementary Figure 1). Induction of apoptosis was timeand dose-dependent, starting in cell line CNE-2 at $24 \mathrm{~h}$ at a concentration of $5,000 \mathrm{U} / \mathrm{ml}$ of IFN $\beta$, and in the other four sensitive cell lines after $48 \mathrm{~h}$ of incubation at IFN $\beta$ concentrations between 100 and 1,000 U/ml. No induction of apoptosis was observed in the nasoepithelial cell line NP69 and the NPC cell line C666-1.

Apoptosis could also be observed when cells were stained with Hoechst 33258. Here, IFN $\beta$ induced morphological changes of apoptosis such as chromatin condensation and nuclear blebbing in the five sensitive 

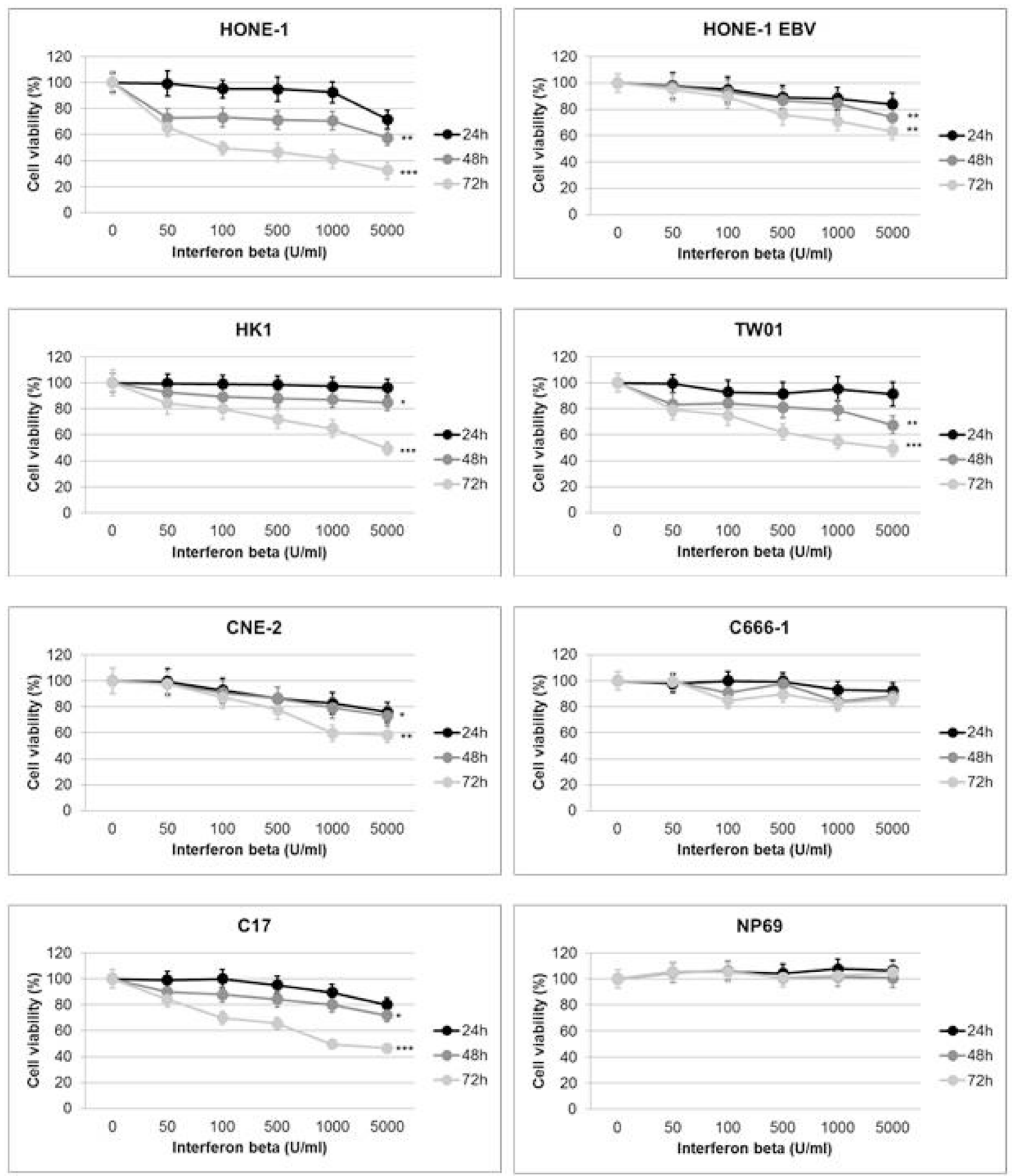

Figure 1: IFN $\beta$ decreases viability of NPC cells. IFN $\beta$ decreases cell viability in a dose-dependent way starting $24 \mathrm{~h}$ after incubation. After $48 \mathrm{~h}$ and $72 \mathrm{~h}$ of incubation with IFN $\beta$ a significant reduction in cell viability is observed in NPC cell lines HONE-1, HONE-1 EBV, CNE-2, HK-1, TW01 and C17-PDX cells. No effect is seen in the nasoepithelial cell line NP69 and NPC cell line C666-1. Cell viability was measured by Rotitest Vital. Cells were plated in quintuplicates in 96-well plates. Data are presented as means \pm S.E.M., each experiment was done three times (Student's $t$-test; ${ }^{*} P<0.05 ;{ }^{* *} P<0.01 ;{ }^{* * *} P<0.001$ ). 
NPC cell lines, whereas no such effect was observed in the nasoepithelial cell line NP69 and the NPC cell line C666-1 (Figure 2B).

As the apoptotic phenotype can be induced via caspase-dependent but also caspase-independent mechanisms [25], we investigated whether the induction of apoptosis in NPC cells by IFN $\beta$ involved the effector caspase-3. Cells were treated as above and stained with an antibody recognizing only the active form of caspase- 3 . As shown in Figure $2 \mathrm{C}$, IFN $\beta$ induced activation of caspase-3 in a dose-dependent way in NPC cell lines HONE-1, HONE-1 EBV, HK-1, TW01, CNE-2 and in C17-PDX cells. No activation of caspase- 3 was seen in the nasoepithelial cell line NP69 and NPC cell line C6661. In summary, these experiments demonstrate that IFN $\beta$ induces apoptosis at concentrations achievable in humans in a caspase-dependent way in the majority of NPC cell lines as well as PDX cells but not nasoepithelial cells.

\section{Induction of apoptosis by IFN $\beta$ is dependent on caspase-8}

There are two major pathways leading to the activation of effector caspases such as caspase-3, the intrinsic pathway inducing through mitochondrial damage the activation of procapase-9, and the extrinsic pathway in which procaspases- 8 or -10 are activated upfront [26]. Using a panel of different caspase-inhibitors we aimed to dissect the effect of different caspases on the induction of apoptosis in NPC cells. Cells of different NPC cell lines and cell line NP69 were treated for $72 \mathrm{~h}$ with $1,000 \mathrm{U} / \mathrm{ml}$ IFN $\beta$ in the presence or absence of the pan-caspase inhibitor Z-VAD-fmk, the caspase-8-inhibitor Z-IETD-fmk or the caspase-9 inhibitor Z-LEHD-fmk. In all IFN $\beta$-sensitive cell lines Z-VAD-fmk and Z-IETDfmk effectively blocked IFN $\beta$-mediated apoptosis. In comparison, Z-LEHD-fmk did not inhibit IFN $\beta$-mediated apoptosis (Figure 3A). These results, therefore, suggest that IFN $\beta$ induces apoptosis in NPC cells via activation of the extrinsic but not the intrinsic apoptotic pathway.

As IFN $\beta$ induced apoptosis in NPC cells starting at $48 \mathrm{~h}$, we asked at what time point activation of caspases occurred. Activation kinetics of caspase-3/7 and caspase- 8 after incubation with IFN $\beta$ were studied using a bioluminescent assay. After $12 \mathrm{~h}$ of incubation caspase- 8 demonstrated significant activation in IFN $\beta$-sensitive cell lines, slightly decreasing after $48 \mathrm{~h}$. Activation of caspase-3 was first observed after $24 \mathrm{~h}$ incubation with IFN $\beta$ and steadily increased thereafter (Figure 3B). No activation of caspases-3 and -8 was seen in NPC cell line C666-1 and nasoepithelial cell line NP69 indicating that resistance to IFN $\beta$-induced apoptosis in these cells is upstream of the caspase cascade. Activation of caspases 3- and -8 was also demonstrated by detection of cleaved products on immunoblot in IFN-sensitive NPC cell lines but not cell line C666-1 and nasoepithelial cells (Figure 3C).

\section{The TRAIL signaling pathway is intact in NPC cells}

Since caspase- 8 can be activated after binding of death ligands TRAIL (tumor necrosis factor-related apoptosis inducing ligand) or FASLG (Fas ligand) to their respective receptors TRAIL-R1 and 2 and FAS [27], we were interested whether the TRAIL- and FASLG-signaling pathways were functional in NPC cells. In a first step, we examined the expression of TRAIL-R1 and -R2 and FAS in our panel of NPC cell lines, C17-PDX cells and the nasoepithelial cell line NP69 using flow cytometry. Whereas expression of TRAIL-R1 could not be detected in any of the NPC cell lines studied, we were able to demonstrate high expression of TRAIL-R2 in five out of six NPC cell lines; only weak expression of TRAIL-R2 was observed in cell line C666-1 and C17-PDX cells. Of the six NPC cell lines surface expression of FAS could only be detected at low level in cell line C666-1 and in C17-PDX cells. In contrast, the nasoepithelial cell line did not express TRAIL-R2 but showed surface expression of TRAIL-R1 and FAS (Figure 4A).

We next determined the functionality of the TRAIL/ FASLG pathway in NPC cells. Cells were incubated with recombinant human TRAIL $(0.1 \mu \mathrm{g} / \mathrm{ml})$ or FASLG $(0.1 \mu \mathrm{g} / \mathrm{ml})$ for $24 \mathrm{~h}$. Apoptosis was determined via flow cytometry of propidium-iodide stained nuclear DNA. Figure 4B demonstrates that all NPC cell lines as well as C17-PDX cells significantly underwent apoptosis after 24 $\mathrm{h}$ incubation with TRAIL. Apoptosis involved activation of caspase-3 as shown in Figure 4C. In cell line NP69 no signs of apoptosis were detected, even after $72 \mathrm{~h}$ (data not shown). In contrast, all cell lines as well as PDX cells were resistant to induction of apoptosis by FASLG.

We also examined expression of TRAIL-R1, TRAIL-R2 and TRAIL in NPC biopsy specimen from 4 patients by immunohistochemistry. As shown in Figure $4 \mathrm{D}$, similar to the results in the cell line system, in $3 / 4$ patients TRAIL-R2 but not TRAIL-R1 (only in 1/4 patients) was expressed in tumor cells; expression of TRAIL-R2 was of low to moderate intensity and showed a predominant membranous staining pattern. No expression of TRAIL was detected on tumor cells, whereas such expression was found on tumor-infiltrating lymphocytes.

Since in C17-PDX cells expression of Trail-R1 was absent and expression of TRAIL-R2 low, and in a recent analysis on the expression of TRAIL receptors in tumors of 174 patients with NPC, TRAIL-R1 and -R2 were detected only in $29.9 \%$ and $36.2 \%$ of tumors, respectively [28], we asked whether incubation of NPC cells with IFN $\beta$ would increase expression of TRAIL receptors. As shown in Figure 4E and Table 1 IFN $\beta$ markedly increased expression of TRAIL-R2 in C17-PDX cells (60\% after $72 \mathrm{~h}$ ) and all NPC cell lines except of cell line C6661. A weaker induction of expression of TRAIL-R1 was observed in all NPC cell lines including C666-1 and C17- 
A
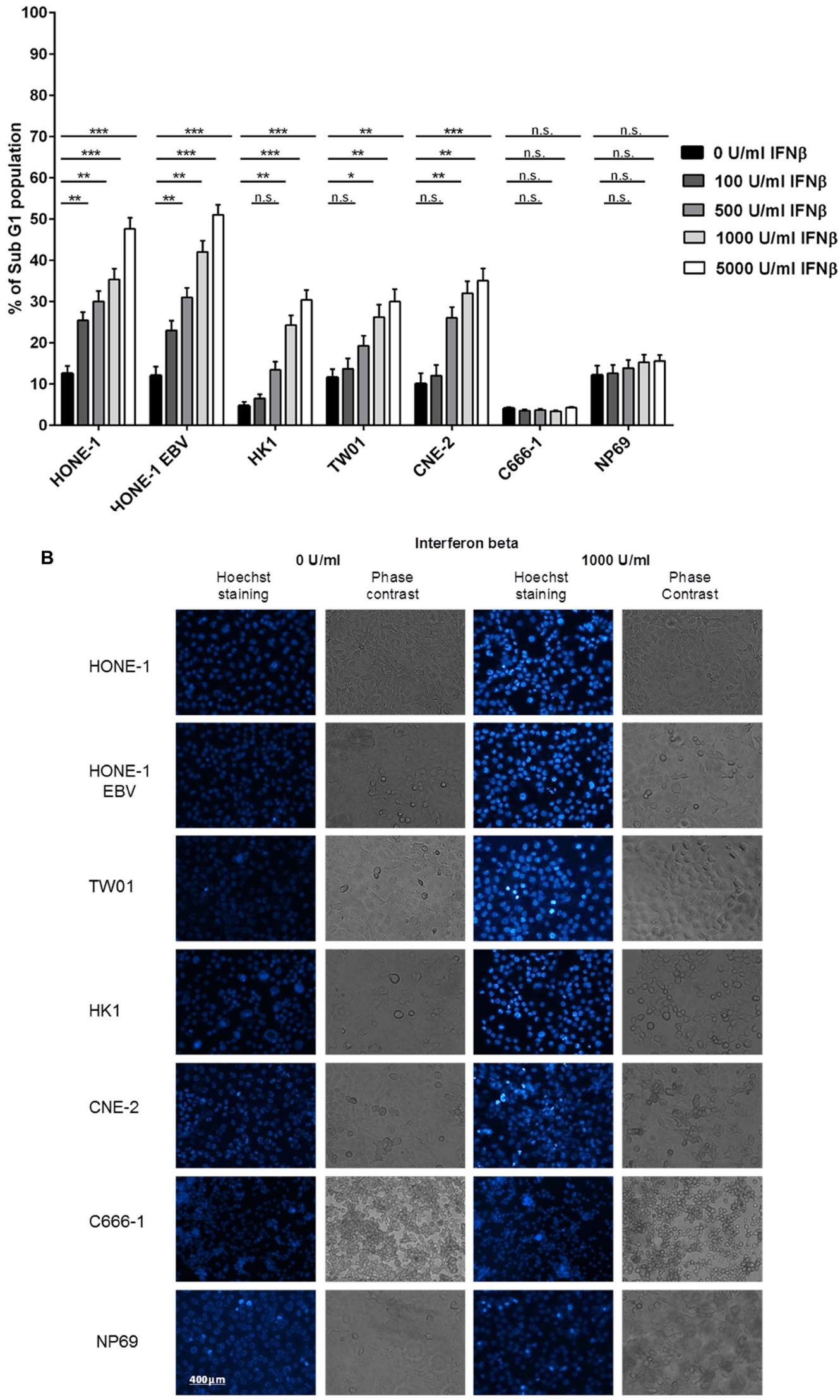


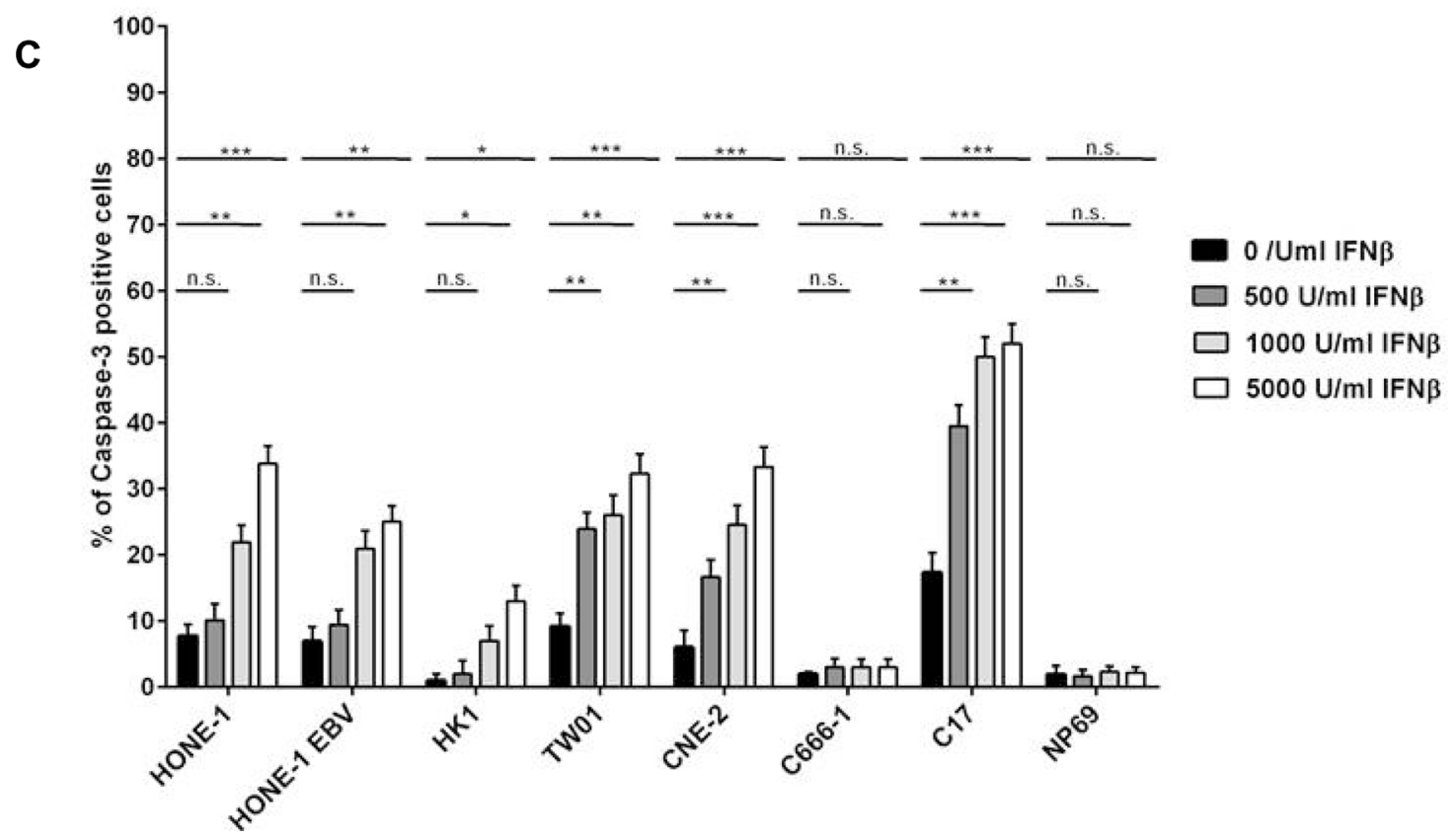

Figure 2: IFN $\beta$ induces apoptosis in NPC cells. (A) Cell cycle analysis. IFN $\beta$ induces apoptosis measured by an increase in subG1 in NPC cell lines HONE-1, HONE-1 EBV, CNE-2, HK-1 and TW01. No effect is seen in NPC cell line C666-1 and the nasoepithelial cell line NP69. The data represent the means of three independent experiments and the corresponding standard error. (B) Hoechst 33258 staining. Treatment with IFN $\beta$ leads to morphological signs of apoptosis (condensed and fragmented nuclei) in NPC cell lines HONE-1, HONE-1 EBV, CNE-2, HK-1 and TW01, but not in cell line C666-1 and the immortalized nasoepithelial cell line NP69. Morphologic changes were examined under a fluorescence microscope at $200 \times$ magnification. Phase contrast images are shown to compare for cell density. (C) Treatment with IFN $\beta$ increases the number of cells with activated caspase-3 in the five IFN-sensitive NPC-cell lines and in C17-PDX cells but not in cell line C666-1 and nasoepithelial cells. Quantitative data are reported as means \pm S.E.M. (triplicate samples). Data of all experiments are shown at $72 \mathrm{~h}$ after incubation with IFN $\beta .{ }^{*} p<0.05 ;{ }^{* *} p<0.01 ;{ }^{* * *} p<0.001$.

PDX cells. No induction or change of expression of FAS after incubation with IFN $\beta$ was noted (data not shown).

\section{IFN $\beta$ induces surface expression of TRAIL in NPC cells}

Since we showed that IFN $\beta$ induced apoptosis in NPC cells via the extrinsic apoptotic pathway and that the TRAIL-signaling pathway was intact in these cells, we wondered whether IFN $\beta$ induced expression of TRAIL in NPC cells. To answer this question, NPC cells were incubated with IFN $\beta$ up to $72 \mathrm{~h}$ and surface expression of TRAIL was analyzed by flow cytometry (Figure 5A) and by confocal microscopy (Figure $5 \mathrm{~B}$ ). Whereas none of the cell lines expressed TRAIL at baseline, expression of TRAIL was observed starting $24 \mathrm{~h}$ after incubation with IFN $\beta$ in six of seven NPC cell lines and C17-PDX cells. IFN $\beta$ did not induce expression of TRAIL in the nasoepithelial cell line NP69 and NPC cell line C666-1.

\section{IFN $\beta$ induces apoptosis in NPC cells through the TRAIL-signaling pathway}

As IFN $\beta$ induced the expression of TRAIL in NPC cells and the TRAIL signaling pathway was intact in these cells, we asked whether endogenous TRAIL was in fact responsible for the induction of apoptosis by IFN $\beta$ in NPC cells. Therefore, neutralization experiments were done using an anti-human TRAIL mAb. NPC cells were treated with $1,000 \mathrm{U} / \mathrm{ml}$ IFN $\beta$ for $72 \mathrm{~h}$ in the presence or absence of a neutralizing anti-human TRAIL mAb. Apoptosis was then analyzed measuring the subG1-DNA content of cells by flow cytometry. Whereas IFN $\beta$ alone induced apoptosis in all IFN $\beta$-sensitive cell lines and C17-PDX cells, apoptosis was inhibited by coincubation of cells with anti-TRAIL-antibody (Figure 6A and 6B). In order to evaluate whether the induction of apoptosis by IFN $\beta$ was based on de novo synthesis of TRAIL, TRAIL mRNA-expression was silenced by specific TRAIL-siRNA before treatment of cells with IFN $\beta$. The efficiency of siRNA-knock down was monitored by measuring TRAIL-surface expression after IFN $\beta$ treatment via flow cytometry (Supplementary Figure 2). As shown in Figure 6C and 6D transfection of NPC cells with TRAIL-siRNA but not scr-RNA abrogated IFN $\beta$-induced apoptosis. These results indicate that IFN $\beta$ induces apoptosis in NPC cells via the expression of endogenous TRAIL and subsequent activation of the TRAIL-signaling pathway. 
A
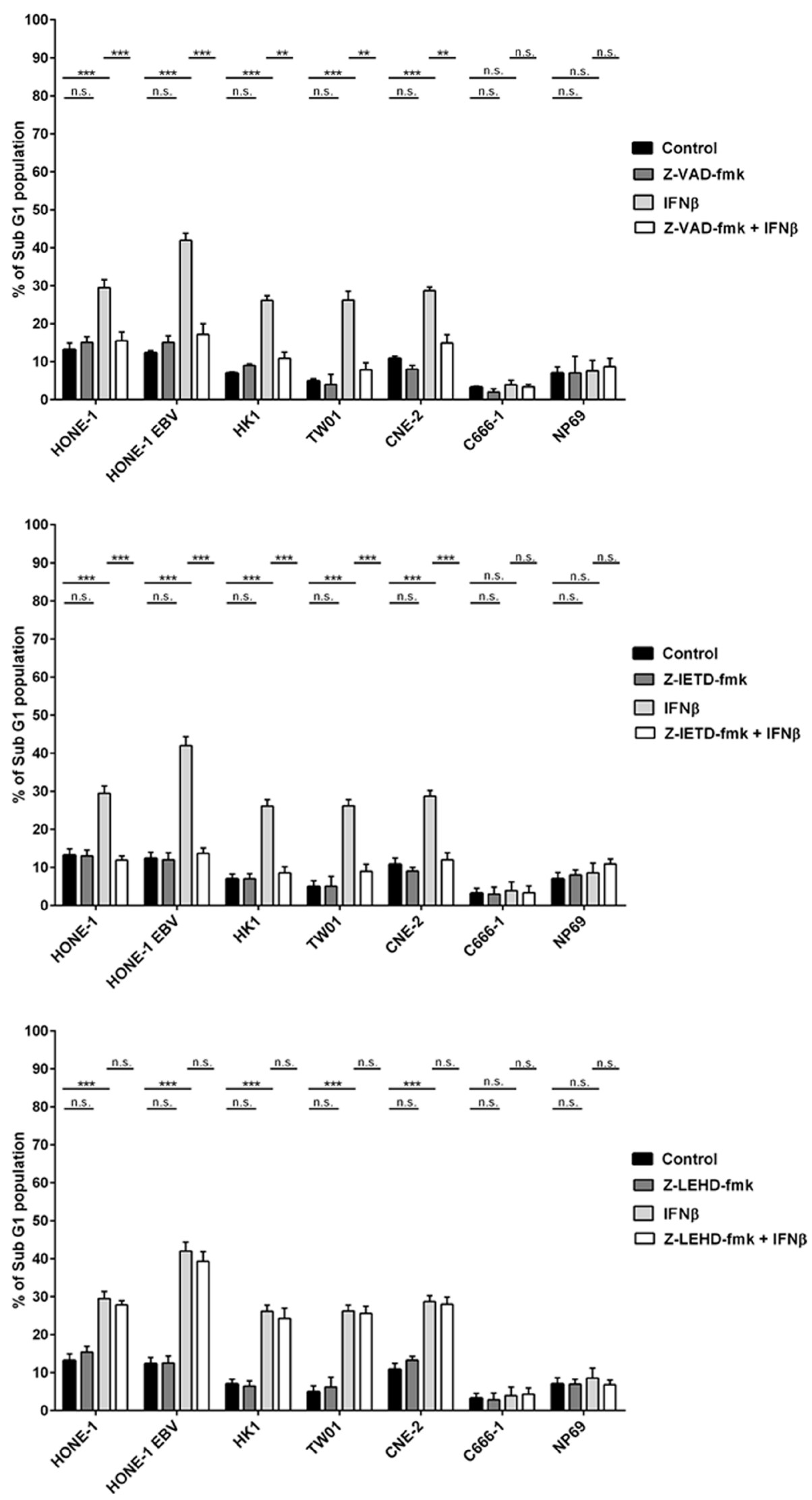
B
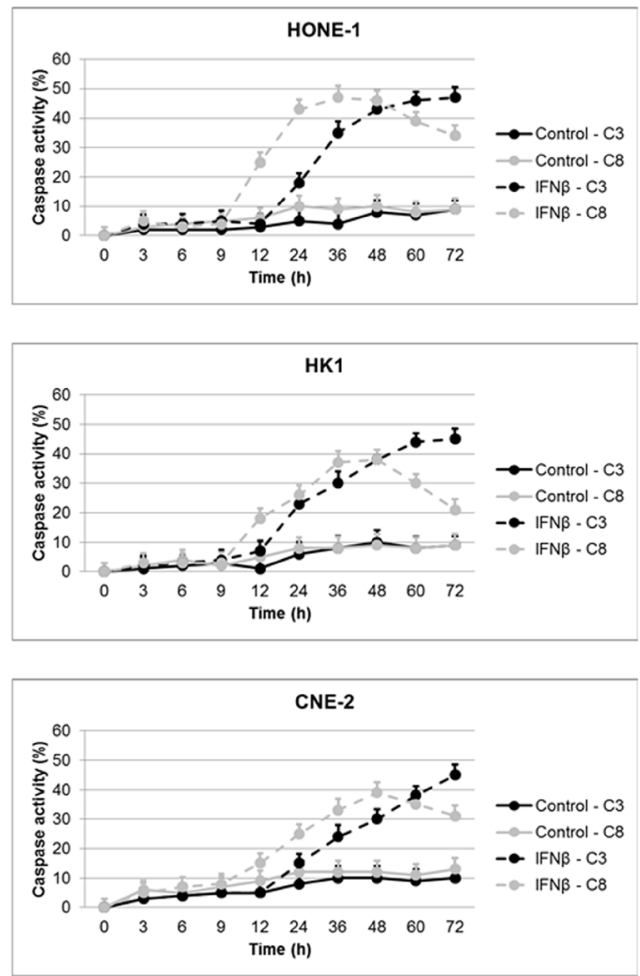
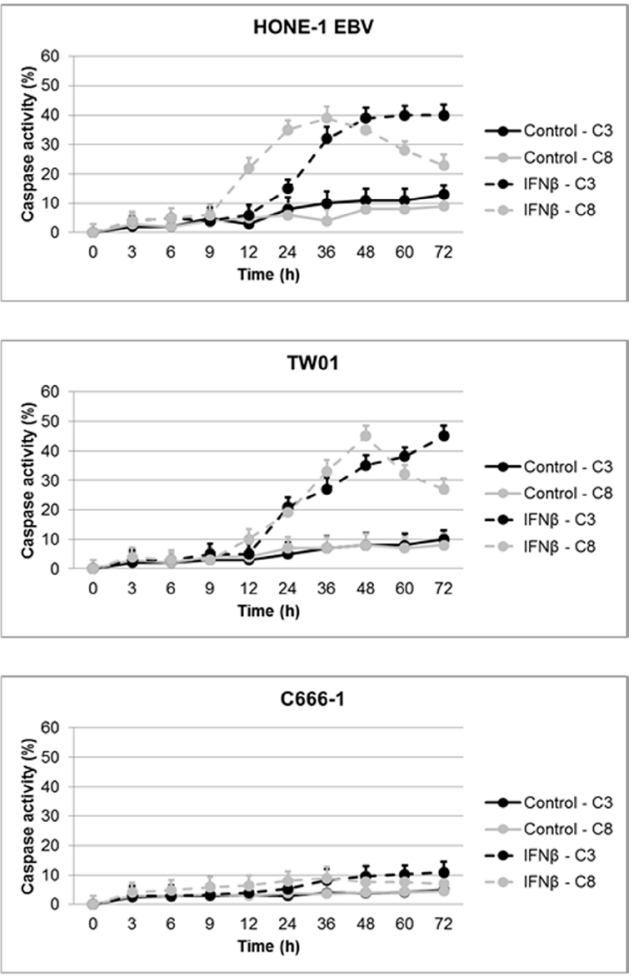
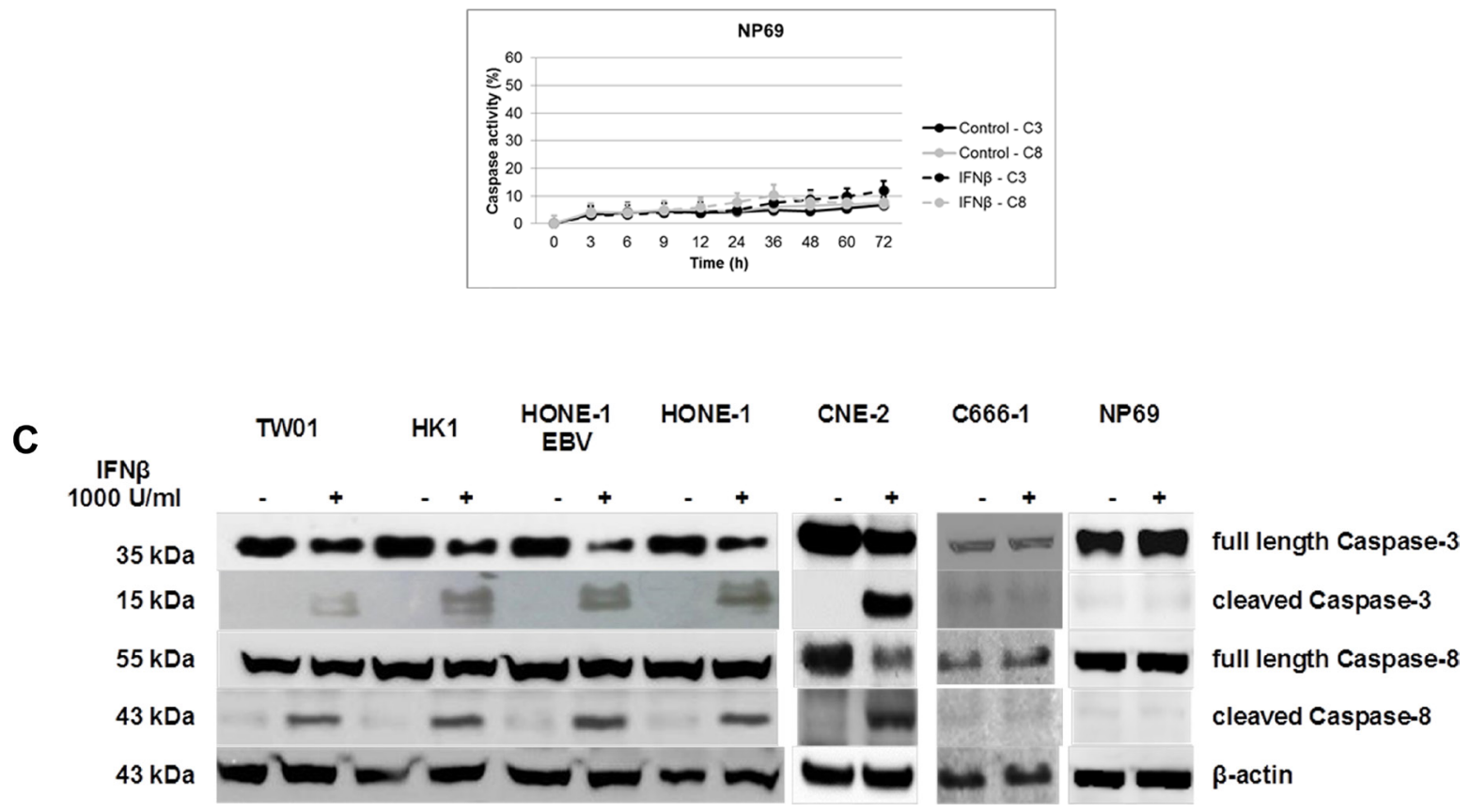

Figure 3: IFN $\beta$ induces apoptosis via the extrinsic pathway in NPC cells. (A) Effect of caspase inhibitors on NPC cells treated with IFN $\beta$. Pretreatment of NPC cells with the pan-caspase inhibitor Z-VAD-fmk or the caspase-8 inhibitor Z-IETD-fmk but not the caspase-9 inhibitor Z-LEHD-fmk inhibits IFN $\beta$-mediated apoptosis in IFN $\beta$-sensitive NPC cell lines. Inhibitors were added at $10 \mu \mathrm{M}$ $1 \mathrm{~h}$ prior to IFN $\beta$. Apoptosis was determined by measurement of subG1-content. Data of all experiments are shown at $72 \mathrm{~h}$ after IFN $\beta$ treatment. Quantitative data are reported as means \pm S.E.M. (triplicate samples). $: p<0.05 ;{ }^{* *}: p<0.01 ;{ }^{* * *}: p<0.001$ (B) Activation kinetics of caspases- 8 , and $-3 / 7$ in NPC-cells treated with IFN $\beta$ for $72 \mathrm{~h}$. Activation of caspase- 8 starts at $12 \mathrm{~h}$ of incubation with IFN $\beta$, activation of caspases-3/7 is first noted after $24 \mathrm{~h}$. Caspase activation was measured by the Caspase $\mathrm{Glo}^{\circledast}$ assay as described in the method section. Quantitative data are reported as means \pm S.E.M. $(n=5)$. (C) Immunblot for caspases- 8 and -3 . Treatment with IFN $\beta$ leads to cleavage of caspases- 8 and -3 in IFN $\beta$-sensitive NPC cell lines but not in NPC cell line C666-1 and nasoepithelial cell line NP69. Cells were treated for $24 \mathrm{~h}$ with $1,000 \mathrm{U} / \mathrm{ml}$ IFN $\beta$. 
A

TRAIL-R1 Expression L'] Isotype $\square$ TRAIL-R1
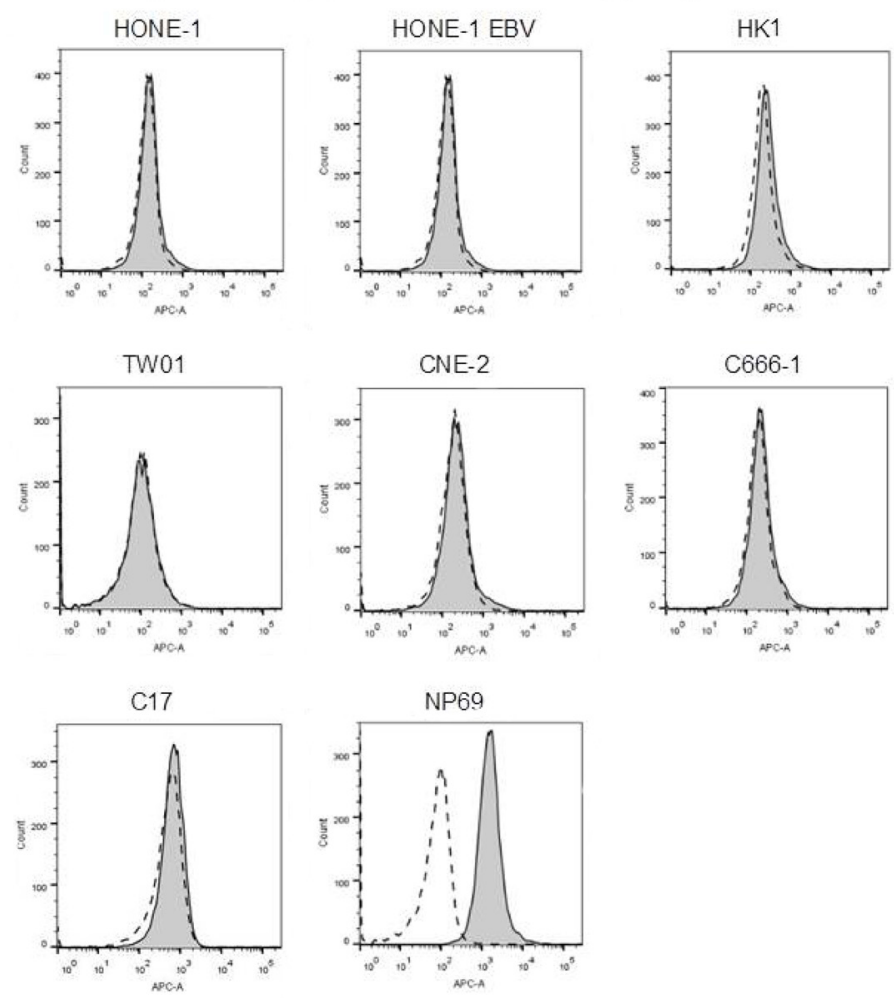

TRAIL-R2 Expression

L'] Isotype

TRAIL-R2
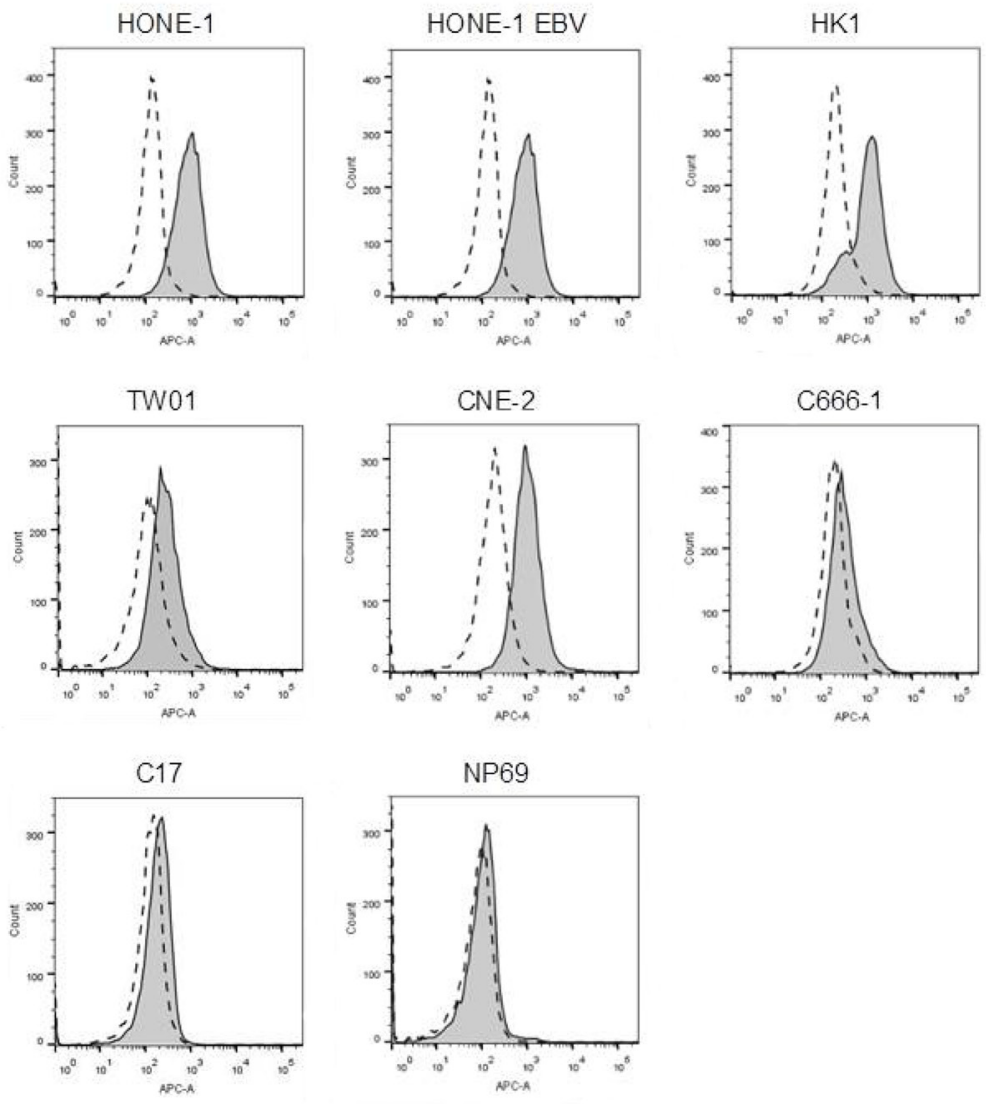
FAS Expression

HONE-1

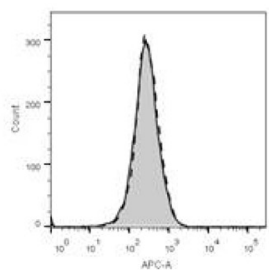

TW01

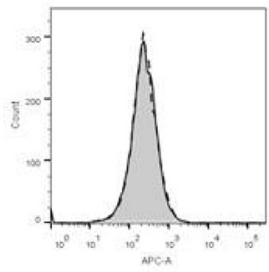

C17

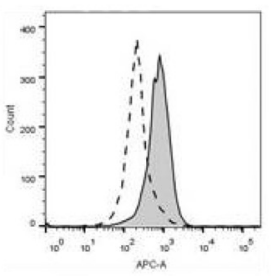

B
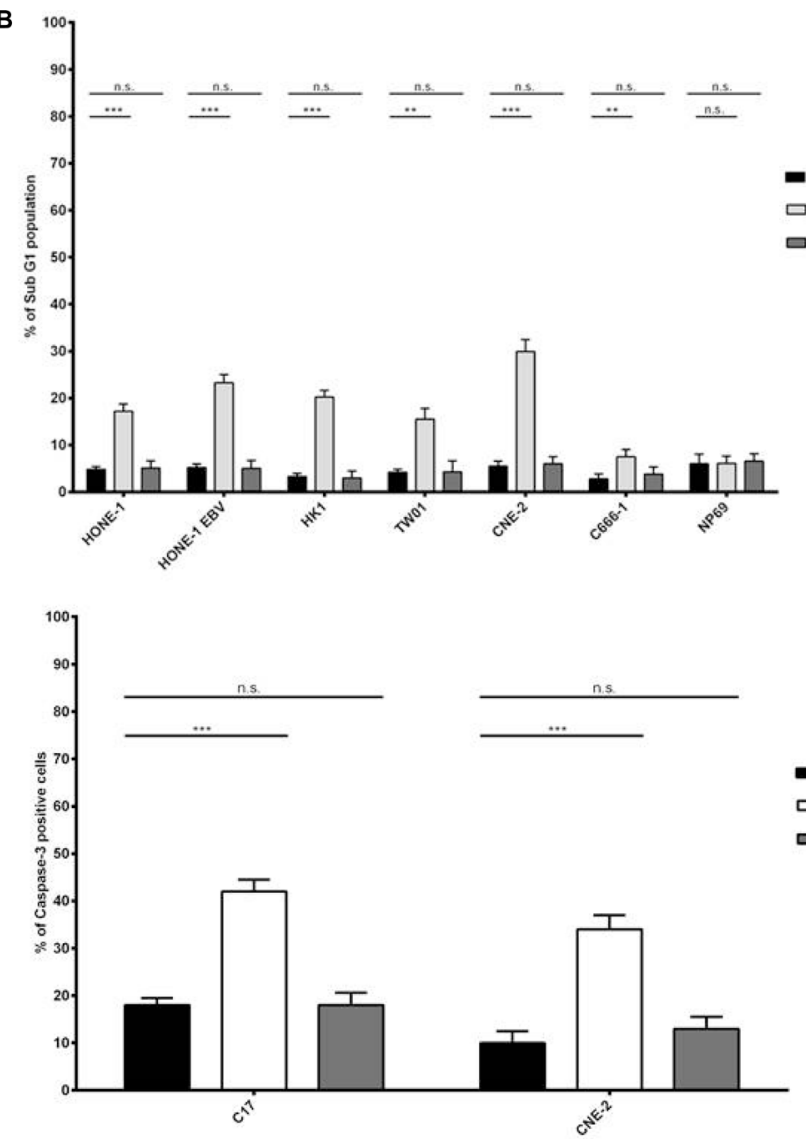

HONE-1 EBV

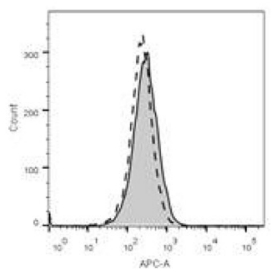

CNE-2

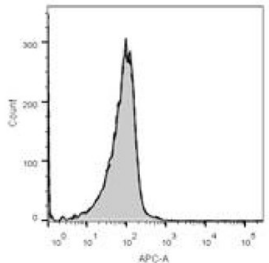

NP69

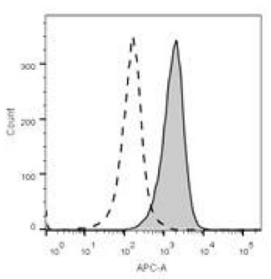

$\square$ FAS

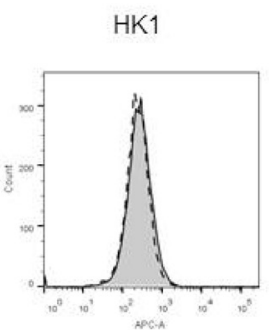

C666-1

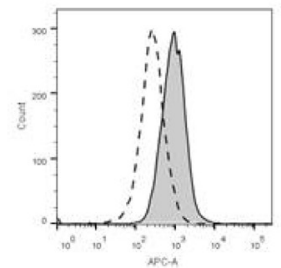

- Control

口 FAS Ligand

口 TRALL

口 FAS Ligand 


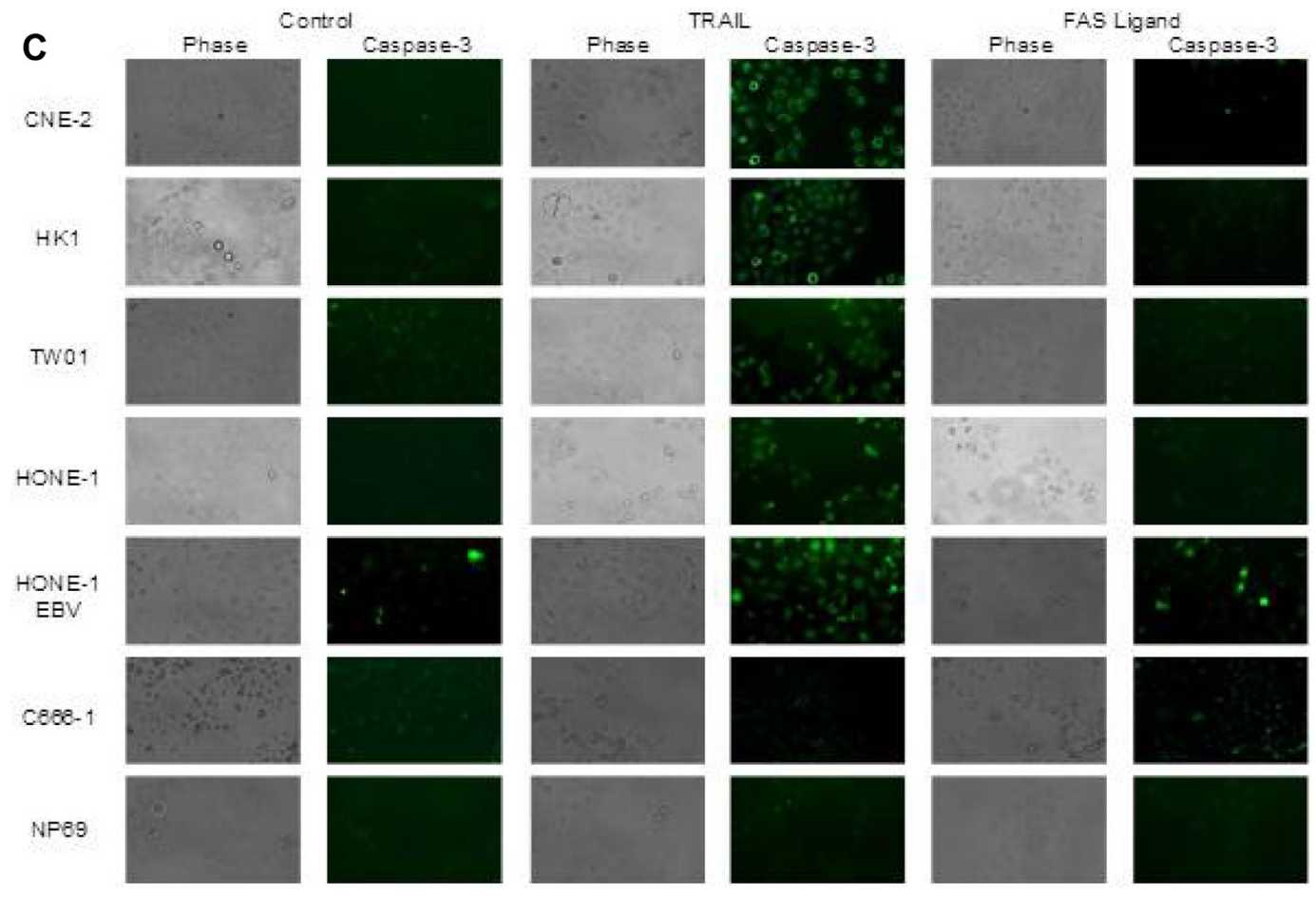

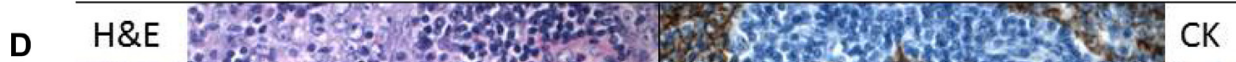

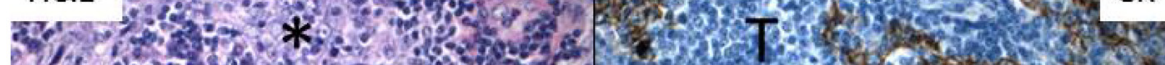

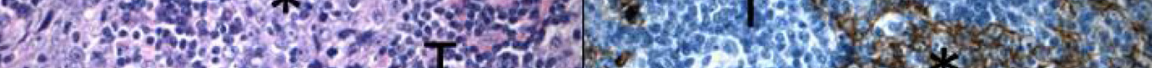

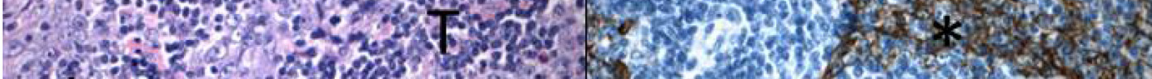

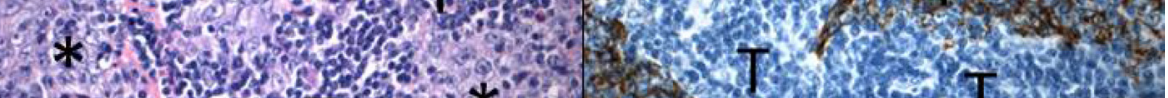

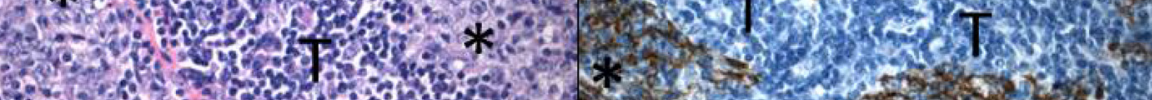

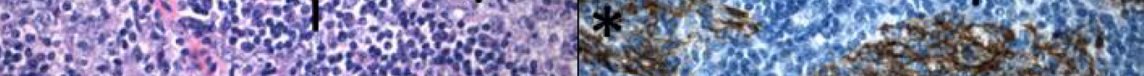
30.

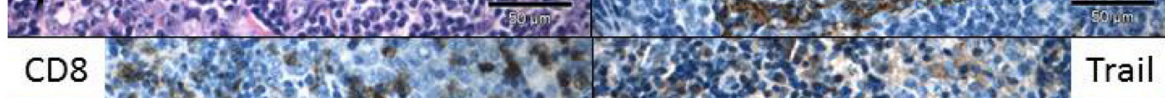

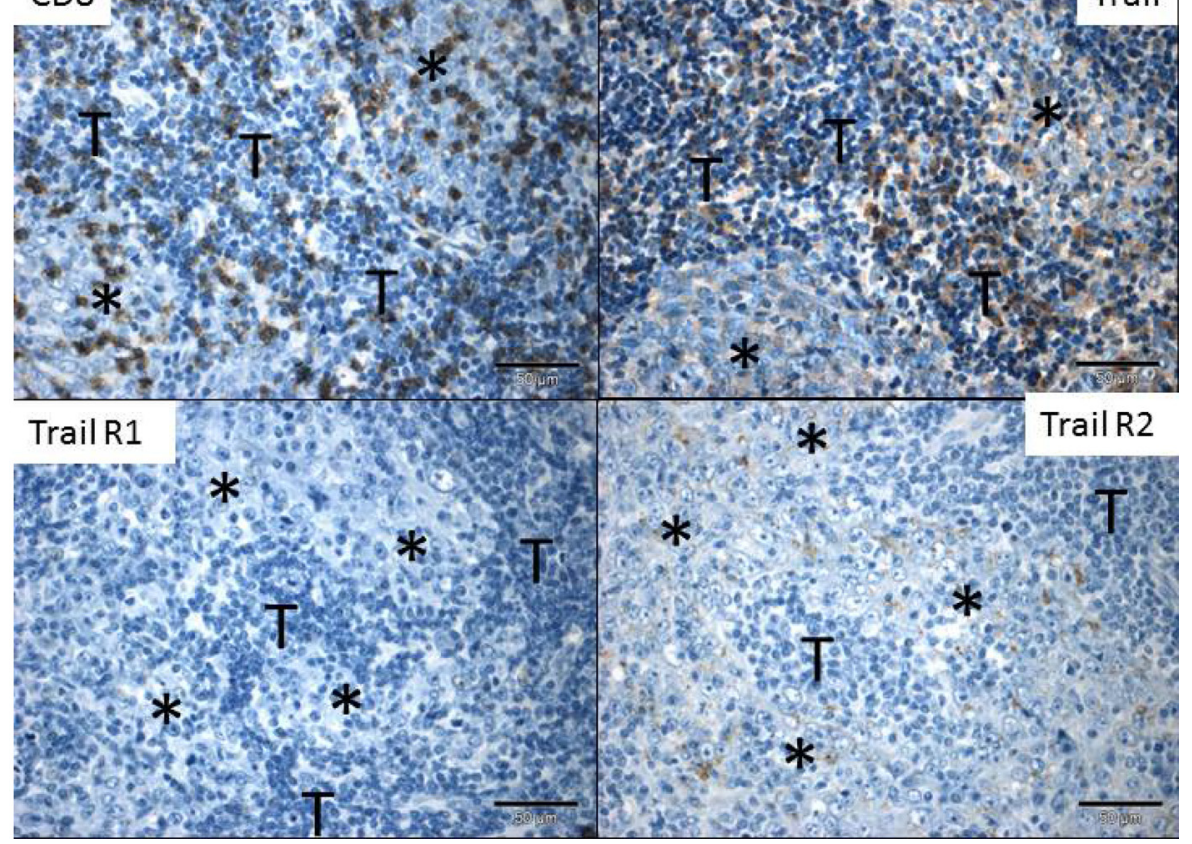


E

HONE-1

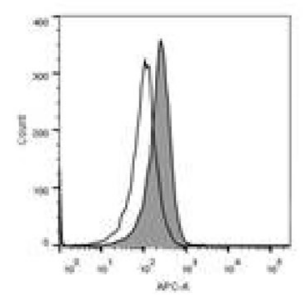

HONE-1

EBV

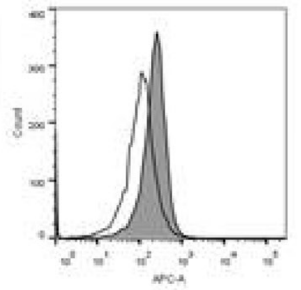

TW01

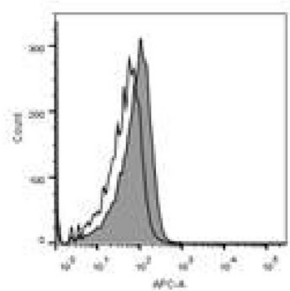

C666-1

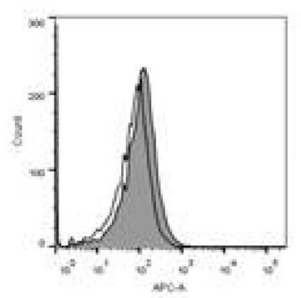

$C 17$

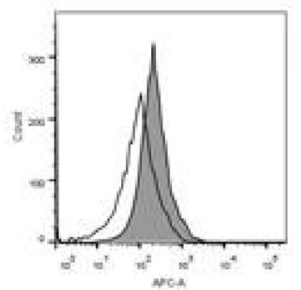

NP69

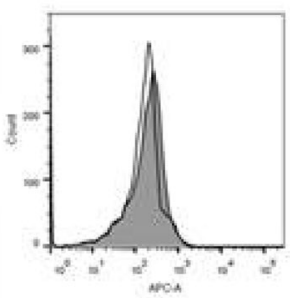

IFNB
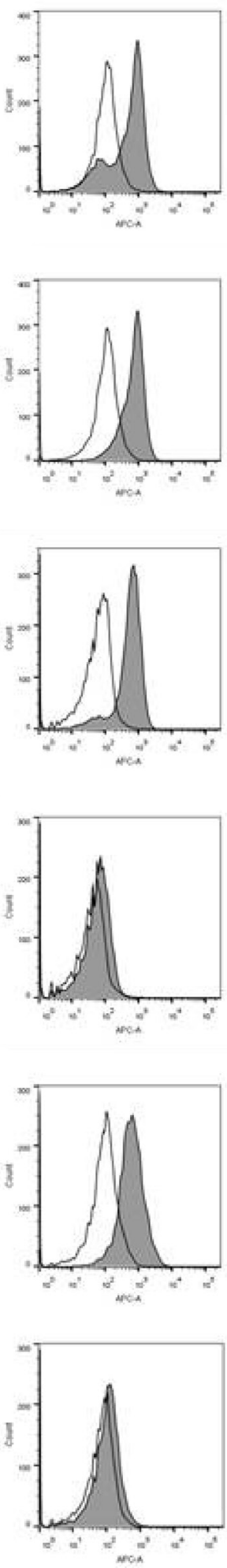

Figure 4: TRAIL induces apoptosis in NPC cells. (A) Surface expression of TRAIL-R1, TRAIL-R2 and FAS in NPC cells. TRAIL-R2 is expressed in all NPC cell lines but not nasoepithelial cells; low expression in cell line C-666-1 and C17-PDX cells; no expression of TRAIL-R1 in NPC cell lines but nasoepithelial cells. No expression of FAS except in nasopepithelial cells and low in NPC cell line C666-1 and C17-PDX cells. Data were acquired by flow cytometry and were compared to specific isotype controls. (B) Induction of apoptosis via TRAIL in NPC cell lines but not nasopepithelial cells. Cells were exposed to TRAIL ( $0.1 \mu \mathrm{g} / \mathrm{ml})$ or FAS Ligand $(0.1 \mu \mathrm{g} / \mathrm{ml})$ for $24 \mathrm{~h}$. The percentage of apoptotic cells was determined by flow cytometry of cells with subG1-content. Quantitative 
data are reported as means \pm S.E.M. (triplicate samples). ${ }^{*} p<0.05 ;{ }^{* *} p<0.01 ;{ }^{* * *} p<0.001$. (C) Immunofluorescence for active caspase-3. Treatment with TRAIL $(0.1 \mu \mathrm{g} / \mathrm{ml})$ for $24 \mathrm{~h}$ induced the expression of active caspase- 3 in five out of six NPC cell lines. No induction of active caspase-3 was observed when NPC cells were incubated with FAS Ligand. Active caspase-3 was examined under a fluorescence microscope at $200 \times$ magnification. (D) Immunohistochemistry for TRAIL-R1, TRAIL-R2 and TRAIL in an NPC tumor. NPC cells $\left({ }^{\star}\right)$ stained by cytokeratin, show partially a low to moderate, predominantely membranous, less cytoplasmic expression of TRAIL-R2 and no expression of TRAIL-R1 or TRAIL; a subpopulation of tumor-infiltrating lymphocytes (T), in part stained by CD8, express TRAIL. All images at 400× magnification. Representative images of one NPC tumor are shown; similar staining patterns were obtained in NPC tumors of two other patients analyzed. (E) Surface expression of TRAIL-R2 after incubation of cells with IFN $\beta$. Cells were incubated for $72 \mathrm{~h}$ with (gray area) or without (white area) $1,000 \mathrm{U} / \mathrm{ml}$ IFN $\beta$ and then stained and analyzed as in (A). IFN $\beta$ upregulated TRAIL-R2 expression in NPC cell lines HONE, HONE-EBV, TW01 as well as C17-PDX cells but not in C666-1 cells and nasoepithelial cells.

\section{DISCUSSION}

In this study we have shown that IFN $\beta$ induces apoptosis in the majority of NPC cell lines and in cells of a patient-derived xenograft at concentrations achievable in humans and that the mechanism of induction of apoptosis is based on the expression of TRAIL in NPC cells and subsequent activation of the TRAIL-signaling pathway in an autocrine way.

Interferons are pleiotropic cytokines which can act on tumor cells directly or indirectly via immune effector cells [12]. Type I interferons, of which IFN $\alpha$ and $\beta$ are the most prominent members, act through the type I receptor which is composed of two subunits, IFNAR1 and IFNAR2. Type I interferons have been shown to induce apoptosis in cancer cell lines of various origins in a cell type-specific way. In neuroblastoma cells IFN $\beta$ induced apoptotic cell death through the intrinsic pathway by downregulation of phosphatidylinositol 3-kinase/AKT signaling, cytochrome $\mathrm{C}$ release and activation of procaspase 9 [18]. In contrast, in melanoma and breast cancer cells IFN $\beta$ has been shown to induce apoptosis via the extrinsic signaling pathway dependent on the expression of TRAIL [19-20]. In cervical cancer, however, type I interferons induced apoptosis via the extrinsic pathway by balancing cFLIP and caspase- 8 independent of death ligands [29]. In our experiments, IFN $\beta$-induced apoptosis was caspase-dependent and could be blocked by using inhibitors against caspase- 8 but not caspase-9 indicating a role for the extrinsic but not intrinsic apoptotic pathway. As in the melanoma and breast cancer system we could demonstrate that IFN $\beta$ upregulated expression of TRAIL and that IFN $\beta$-induced apoptosis could be inhibited by an anti-TRAIL-antibody and TRAIL-siRNA [19-20]. Expression of TRAIL on the surface of NPC cells was noted after $24 \mathrm{~h}$ of incubation with IFN $\beta$, activation of caspases- 8 and -3 starting at 24 $\mathrm{h}$ and $48 \mathrm{~h}$, respectively, and first signs of apoptosis were noted at $48 \mathrm{~h}$. The time kinetic was similar to the one described for melanoma and breast cancer cell lines [1920]. IFN $\beta$ has also been demonstrated to induce TRAILsurface expression in $\mathrm{CD} 4+$ and $\mathrm{CD} 8+$ peripheral blood $\mathrm{T}$ cells following CD3-stimulation as well as in NK-cells [30-31]. As we have demonstrated that the TRAIL-signaling pathway is intact in the NPC cell lines studied, IFN $\beta$ could not only directly by promoting TRAIL-expression on the surface of NPC-cells but also indirectly by expressing TRAIL on immune effector cells, induce apoptosis in NPC cells. This is of importance in cells like NPC cell line C6661 in which IFN $\beta$ does not induce expression of TRAIL and does not directly lead to apoptosis, whereas C666-1 cells are susceptible to apoptosis by exogenous application of TRAIL.

As the biological effects of IFN $\beta$ in NPC cells can be obtained at concentrations which are achieved in the serum of patients treated with IFN $\beta$ [24, 32], it might very well be that the induction of apoptosis in NPC cells via the TRAIL-signaling pathway could at least contribute to the therapeutic effect of IFN $\beta$ observed in patients with NPC. The observation by Wang et al. that tumors from a portion of patients with NPC express TRAIL-R1 (29.9\%) and TRAIL-R2 (36.6\%) and that the expression of TRAIL-R2 was associated with a better survival rate, indicates that the TRAIL-signaling pathway is of importance in the elimination of NPC tumor cells [28]. Our finding that IFN $\beta$ markedly increased expression of TRAIL-R2 in NPC cells including PDX cells, hints that IFN $\beta$ could strengthen this elimination process in vivo making tumor cells susceptible to the induction of apoptosis by TRAIL. That type I interferons induce the expression of TRAIL in vivo, has been shown in neutrophils and monocytes of patients with CML treated with IFN $\alpha$ [33]. In addition, in a phase II trial in patients with metastatic melanoma, TRAIL was detectable in the serum of patients after the application of IFN $\beta$ indicating that the induction of TRAIL by IFN $\beta$ occurred also in vivo [34]. Though only one out of seven patients had a clinical regression after IFN $\beta$, TRAILserum levels were highest in the responding patient. IFN $\alpha$ is licensed as adjuvant therapy in patients with high-risk melanoma as it extends relapse-free and overall survival [35-36]. In mice, IFN $\alpha$ suppresses the formation of metastases by driving a systemic immune response [37]. In children and adolescents with nasopharyngeal carcinoma, metastatic relapses are the major source of treatment failure [4-7]. As this rate is lowest in the two GPOHprotocols using IFN $\beta$ as adjuvant therapy compared to other prospective studies without IFN $\beta$, IFN $\beta$ might well have an antimetastatic effect in NPC.

In conclusions, IFN $\beta$ induces apoptosis in nasopharyngeal carcinoma cells but not nasoepithelial cells through expression of TRAIL and subsequent 
Table 1: Surface Expression of TRAIL-R1 and -R2 in NPC cells in the presence or absence of IFN $\beta$

\begin{tabular}{|c|c|c|c|c|c|c|c|c|c|}
\hline \multirow[b]{2}{*}{ Cells } & \multirow[t]{2}{*}{ Incubation } & \multicolumn{2}{|c|}{$\mathbf{O} \mathbf{h}$} & \multicolumn{2}{|c|}{$24 \mathrm{~h}$} & \multicolumn{2}{|c|}{$48 \mathrm{~h}$} & \multicolumn{2}{|c|}{$72 \mathrm{~h}$} \\
\hline & & Control & IFN $\beta$ & Control & IFN $\beta$ & Control & IFN $\beta$ & Control & IFN $\beta$ \\
\hline \multirow{2}{*}{ HONE-1 } & TRAIL-R1 & $0.02 \pm 2.1$ & $0.02 \pm 1.0$ & $0.04 \pm 2.1$ & $0.07 \pm 2.8$ & $0.3 \pm 0.4$ & $6.1 \pm 0.2$ & $5.8 \pm 0.01$ & $15.0 \pm 0.2$ \\
\hline & TRAIL-R2 & $30.3 \pm 3.2$ & $29.1 \pm 2.2$ & $29.0 \pm 3.1$ & $55.9 \pm 3.0$ & $33.0 \pm 2.5$ & $72.2 \pm 3.3$ & $35.3 \pm 4.5$ & $80.3 \pm 3.2$ \\
\hline \multirow{2}{*}{$\begin{array}{l}\text { HONE-1 } \\
\text { EBV }\end{array}$} & TRAIL-R1 & $0.03 \pm 3.4$ & $0.04 \pm 1.9$ & $0.08 \pm 2.0$ & $0.05 \pm 1.3$ & $0.2 \pm 0.3$ & $5.5 \pm 0.2$ & $6.6 \pm 0.01$ & $13.0 \pm 0.5$ \\
\hline & TRAIL-R2 & $28.8 \pm 2.9$ & $27.1 \pm 1.9$ & $30.7 \pm 4.2$ & $48.0 \pm 1.9$ & $31.1 \pm 1.2$ & $78.0 \pm 2.8$ & $29.0 \pm 3.2$ & $89.9 \pm 2.2$ \\
\hline \multirow{2}{*}{ HK1 } & TRAIL-R1 & $0.02 \pm 2.7$ & $0.03 \pm 3.0$ & $0.1 \pm 0.1$ & $0.9 \pm 0.3$ & $1.1 \pm 0.5$ & $12.3 \pm 0.4$ & $12.9 \pm 0.2$ & $25.0 \pm 0.3$ \\
\hline & TRAIL-R2 & $29.9 \pm 2.2$ & $32.4 \pm 3.0$ & $30.9 \pm 2.7$ & $58.0 \pm 2.3$ & $35.6 \pm 3.1$ & $80.1 \pm 3.3$ & $37.7 \pm 2.3$ & $88.1 \pm 4.1$ \\
\hline \multirow{2}{*}{ TW1 } & TRAIL-R1 & $0.01 \pm 1.3$ & $0.01 \pm 2.3$ & $0.1 \pm 0.2$ & $0.7 \pm 0.2$ & $0.9 \pm 0.2$ & $7.0 \pm 0.2$ & $7.4 \pm 0.2$ & $10.0 \pm 0.2$ \\
\hline & TRAIL-R2 & $16.0 \pm 2.0$ & $16.3 \pm 2.9$ & $16.0 \pm 3.2$ & $39.3 \pm 5.2$ & $18.0 \pm 2.5$ & $69.1 \pm 2.1$ & $15.8 \pm 1.5$ & $84.4 \pm 1.4$ \\
\hline \multirow{2}{*}{ CNE-2 } & TRAIL-R1 & $0.04 \pm 2.2$ & $0.1 \pm 3.4$ & $0.1 \pm 2.3$ & $0.09 \pm 1.8$ & $1.1 \pm 0.2$ & $12.0 \pm 0.7$ & $13.5 \pm 0.1$ & $20.0 \pm 0.2$ \\
\hline & TRAIL-R2 & $40.1 \pm 3.1$ & $38.4 \pm 2.7$ & $47.6 \pm 2.3$ & $46.5 \pm 3.0$ & $67.2 \pm 5.3$ & $68.8 \pm 2.3$ & $77.7 \pm 3.3$ & $80.8 \pm 3.5$ \\
\hline \multirow{2}{*}{ C666-1 } & TRAIL-R1 & $0.04 \pm 3.3$ & $0.05 \pm 2.8$ & $0.06 \pm 3.8$ & $0.1 \pm 3.5$ & $2.0 \pm 0.2$ & $5.2 \pm 0.1$ & $5.5 \pm 0.2$ & $13.0 \pm 0.1$ \\
\hline & TRAIL-R2 & $3.0 \pm 2.2$ & $4.1 \pm 3.4$ & $4.3 \pm 4.0$ & $4.5 \pm 3.2$ & $3.9 \pm 2.2$ & $6.5 \pm 2.5$ & $3.9 \pm 4.2$ & $6.2 \pm 2.5$ \\
\hline \multirow{2}{*}{ C17-PDX } & TRAIL-R1 & $0.07 \pm 3.4$ & $0.09 \pm 2.9$ & $2.2 \pm 2.0$ & $10.1 \pm 2.2$ & $3.0 \pm 0.3$ & $18.1 \pm 0.1$ & $13.2 \pm 0.2$ & $23 \pm 0.5$ \\
\hline & TRAIL-R2 & $6.0 \pm 1.9$ & $5.8 \pm 2.2$ & $5.9 \pm 2.2$ & $37.7 \pm 2.7$ & $6.3 \pm 2.5$ & $40.2 \pm 3.5$ & $5.3 \pm 3.3$ & $60 \pm 2.5$ \\
\hline \multirow[t]{2}{*}{ NP69 } & TRAIL-R1 & $29 \pm 0.5$ & $32 \pm 0.3$ & $28 \pm 0.2$ & $28 \pm 0.5$ & $31 \pm 0.5$ & $31 \pm 0.2$ & $29 \pm 0.5$ & $30 \pm 0.5$ \\
\hline & TRAIL-R2 & $0.05 \pm 2.0$ & $0.06 \pm 0.9$ & $0.08 \pm 1.0$ & $0.04 \pm 3.4$ & $4.8 \pm 3.5$ & $5.5 \pm 3.5$ & $5 \pm 2.2$ & $5 \pm 2.5$ \\
\hline
\end{tabular}

Values are net fluorescent intensities between mean fluorescent intensity of anti-TRAIL-R1 or -R2 antibody and mean

fluorescent intensity of respective isotype. Cells were incubated for indicated time periods with or without 1,000 U/ml IFN $\beta$.

activation of the TRAIL signaling pathway. Further studies to analyze the effect of IFN $\beta$ on the antitumor activity of immune cells against NPC cells as well as the role of IFN $\beta$ on NPC in vivo in the mouse xenograft model are warranted.

\section{MATERIALS AND METHODS}

\section{Cell lines and culture}

Six NPC cell lines and one nasopharyngeal epithelial cell line as a control were used in this study. Cell line CNE-2 was kindly supplied by Prof. Pierre Busson (Gustave Roussy Institute, Paris, France) [38]. Cell line HK1 was obtained from Prof. Lo Kwok Wai from the Chinese University of Hong Kong, China [39]. Cell lines HONE-1, EBV positive - HONE-1 (HONE-1 EBV) [40] and the SV40T-antigen immortalized nasopharyngeal epithelial cell line NP69 [41] were provided by Prof. George Tsao (The Chinese University of Hong Kong, Hong Kong, China). Cell line TW01 was supplied by Prof. Chin-Tarng Lin (National Taiwan University Hospital, Taiwan). Cell line C666-1 was obtained from Prof. FeiFei Liu, University of Toronto, Canada [42].

Cell lines CNE-2, HK1 and TW01 were cultured in Dulbecco's modified Eagle's Medium (PAN Biotech, Dorset, UK). Cell lines C666-1, HONE-1 and HONE1 EBV were maintained in RPMI1640 Medium (Gibco,
Paisley, UK). Both media were supplemented with 10\% fetal bovine serum (Gibco, Paisley, UK), $100 \mathrm{U} / \mathrm{ml}$ penicillin and $100 \mathrm{mg} / \mathrm{ml}$ streptomycin (Gibco, NY, USA). Cells were cultured in a humidified incubator with $95 \%$ air and $5 \% \mathrm{CO}_{2}$ at $37^{\circ} \mathrm{C}$. The nasopharyngeal epithelium cell line NP69 was cultured in keratinocyte-serum free medium (Gibco, NY, USA). All cells were treated with interferon beta (IFN $\beta$ ), TRAIL, or FAS Ligand as indicated below.

\section{Patient-derived xenograft}

The xenograft $\mathrm{C} 17$ was established from a patient with an EBV-positive metastatic NPC by Prof. Pierre Busson, Paris in nude mice [23]. For the experiments described below, single cells suspensions were derived from freshly isolated $\mathrm{C} 17$ tumor fragments by collagenase cell dispersion. C17 cells were kept in culture using RPMI1640 Medium (Gibco) supplemented with $25 \mathrm{mM}$ HEPES, 7, 5\% fetal bovine serum (Gibco) and $100 \mathrm{U} / \mathrm{ml}$ penicillin and $100 \mathrm{mg} / \mathrm{ml}$ streptomycin (Gibco).

\section{Cells authentication: short tandem repeated profiles}

In recent years, two studies have shown that various NPC cell lines were contaminated with HeLa cells which are derived from a cervical carcinoma [43-44]. Thus, we investigated the authenticity of NPC cell lines (C666-1, CNE-2, HK-1, HONE-1, HONE-1 EBV, and TW01) and 

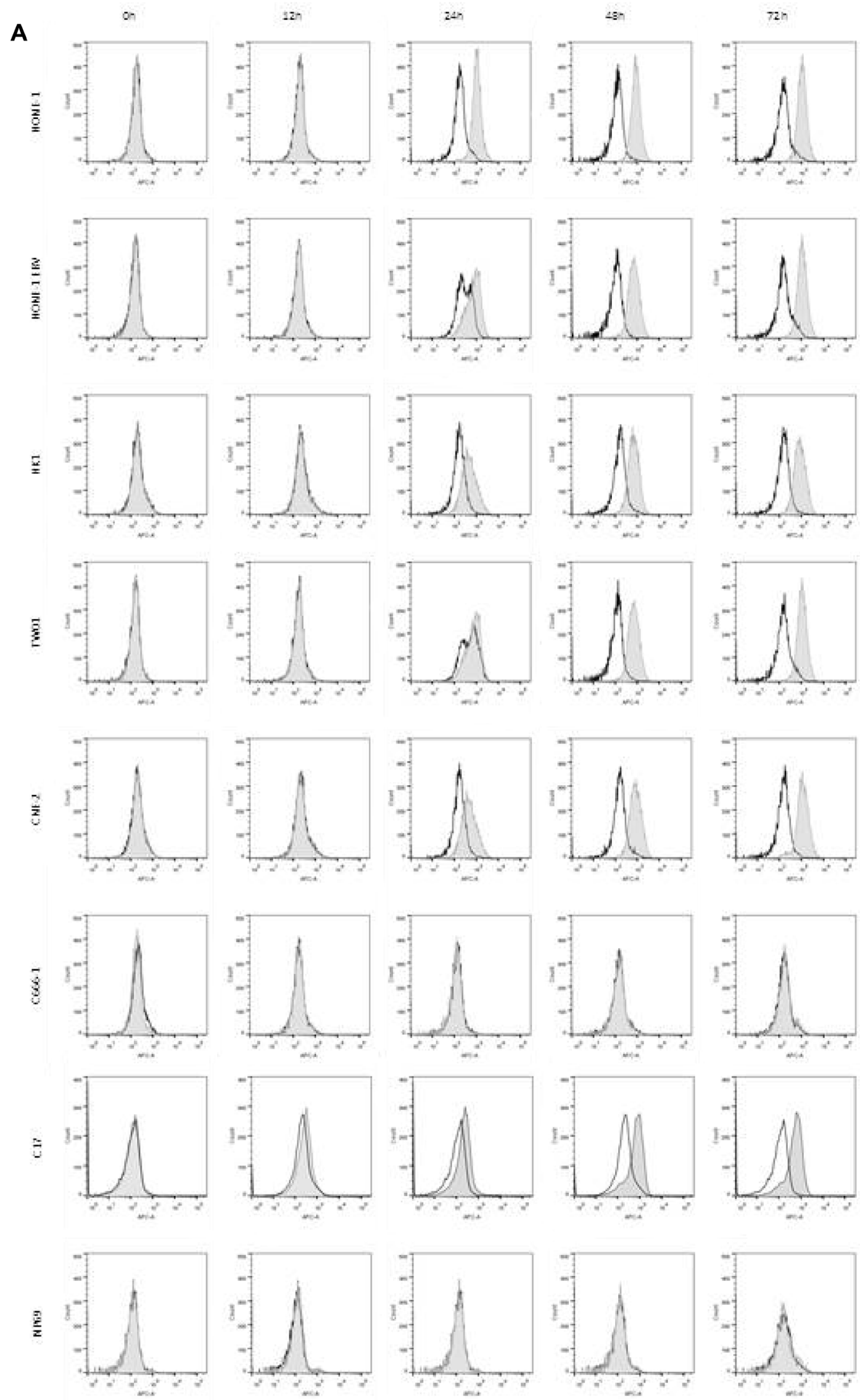


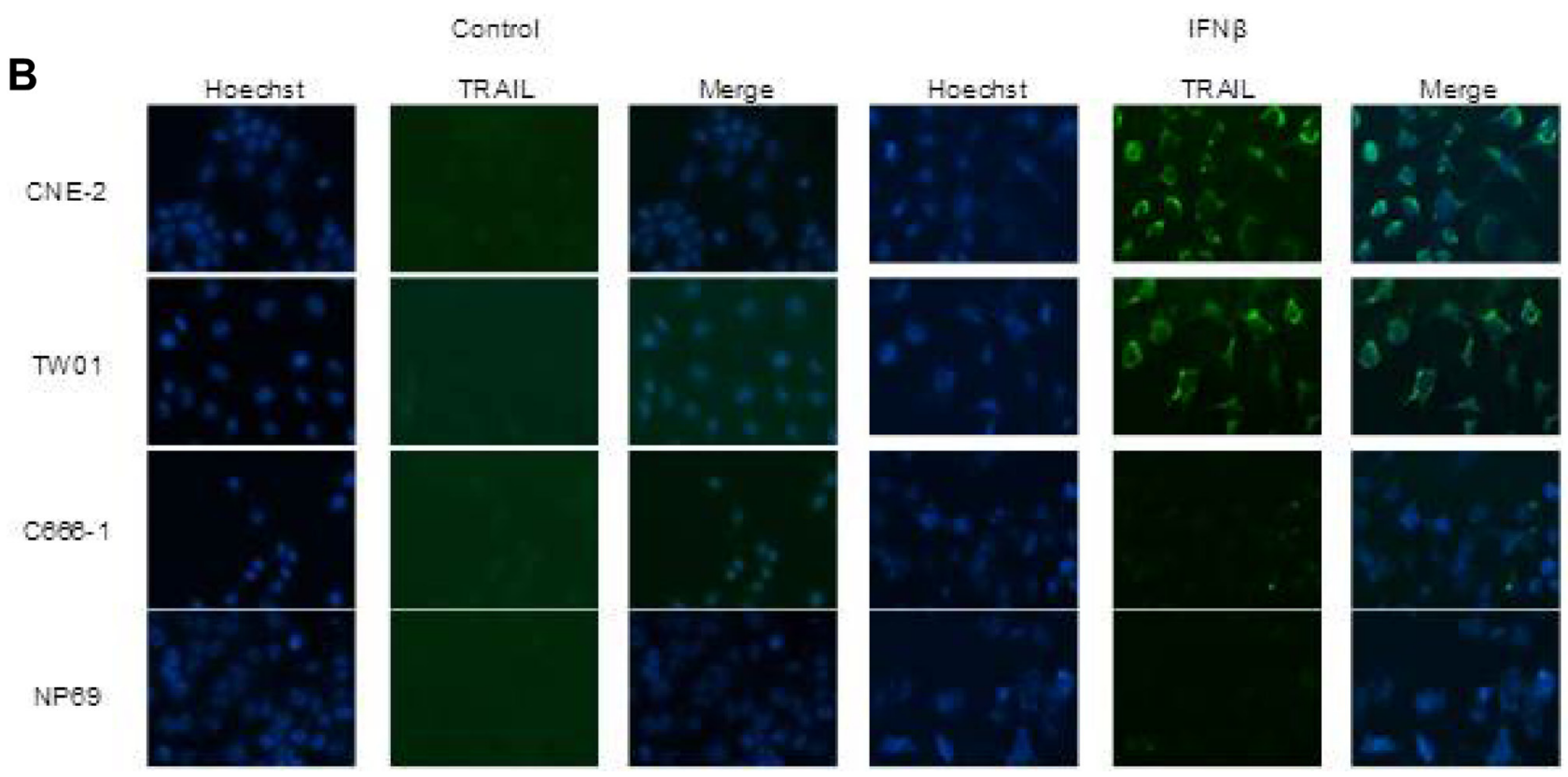

Figure 5: IFN $\beta$ induces surface expression of TRAIL in NPC cells. (A) IFN $\beta$ induces surface expression of TRAIL in NPC cell lines HONE-1, HONE-1 EBV, CNE-2, HK-1, TW01 and C17-PDX cells, but not in cell line C666-1 and the immortalized nasoepithelial cell line NP69. TRAIL-expression was first noted $24 \mathrm{~h}$ after incubation with IFN $\beta$. Cells were incubated with 1,000 U/ml IFN $\beta$ and surface expression was analyzed by flow cytometry comparing IFN $\beta$-treated cells (gray area) against non-treated cells (white area). (B) Immunolocalization of TRAIL in NPC cells. Cells were treated for $72 \mathrm{~h}$ with IFN $\beta$ and stained for TRAIL as described in "Materials and Methods". Nuclei were counterstained with Hoechst 33258. Confocal microscopy at 400× magnification demonstrates predominant localization of TRAIL on the cell surface.

the immortalized nasopharyngeal epithelial cell line (NP69) used in our experiments. DNA of cell lines was extracted and subjected to DNA fingerprinting analysis using the AmpF/STR Identifiler PCR Amplification Kit (Applied Biosystems, Foster City, USA). A total of 15 short tandem repeat (STR) loci (D8S1179, D21S11, D7S820, CSF1P0, D3S1358, TH01, D13S317, D16S539, D2S1338, D19S433, vWA, TPOX, D18S51, D5S818, FGA) and amelogenin were co-amplified in each sample and detected on an ABI Prism 3100 Genetic Analyzer (Applied Biosystems) according to the manufacturer's protocol. Data were analyzed and allele(s) of each locus were determined by GeneScan and Gene-Mapper TM ID Software (Applied Biosystems). Related samples generally yield a result in the $56-100 \%$ match range, and unrelated samples in the $0-55 \%$ match range [45-46]. STR profiles of NPC cell lines and the nasopharyngeal epithelial cell line NP69 are shown in Supplementary Figure 3. STR profiles for NPC cell lines HONE-1, HONE-1 EBV and CNE-2 showed $66 \%$, 66\% and $65 \%$ matching with HeLa cells, respectively, suggesting contamination. In contrast, STR profiles for cell lines HK1, TW01, C666-1 and NP69 matched only between 23\% and 47\% with HeLa cells, ruling out contamination.

\section{Reagents}

Human recombinant interferon beta (IFN $\beta$ ) was obtained from R\&D System (NY, USA). Soluble, recombinant human TRAIL, Super FAS Ligand, the primary mouse monoclonal antibodies against TRAIL, TRAIL-R1 and TRAIL-R2 were purchased from Enzo Life Science (Paris, France). The caspase inhibitors Z-VAD-fmk，Z-IETD-fmk and Z-LEHD-fmk were obtained from R\&D System (Wiesbaden, Germany). Antibodies used for immunoblotting were mouse antihuman $\beta$-actin (Cell Signaling, Danvers, MA, USA), mouse anti-human-TRAIL (Enzo Life Science), mouse anti-human caspase-3 (Cell Signaling), and mouse antihuman caspase-8 (Enzo Life Science). The goat antimouse IgG secondary antibody was purchased from Santa Cruz Biotechnology (Heidelberg, Germany). The FITCactive caspase-3 apoptosis test was obtained from BD Pharmingen (San Diego, CA, USA). Hoechst 33258 was purchased from Sigma (St. Louis, MO, USA), Rotitest Vital from Roth (Karlsruhe, Germany). Knock-down experiments for TRAIL-RNA were performed using TRAIL-siRNA (Dharmacon, Freiburg, Germany, Cat. Nr. L-011524-00-0010) and scrambled RNA (Dharmacon, Cat. Nr. D-001810-20).

\section{Cell proliferation assay}

The WST- 8 reduction assay (Rotitest Vital) was used to determine the effect of IFN $\beta$ ( 0 to $5,000 \mathrm{U} / \mathrm{ml}$ treatment for 24,48 and $72 \mathrm{~h}$ ) on cell viability. The assay was performed as reported before [47]. Briefly, cells 

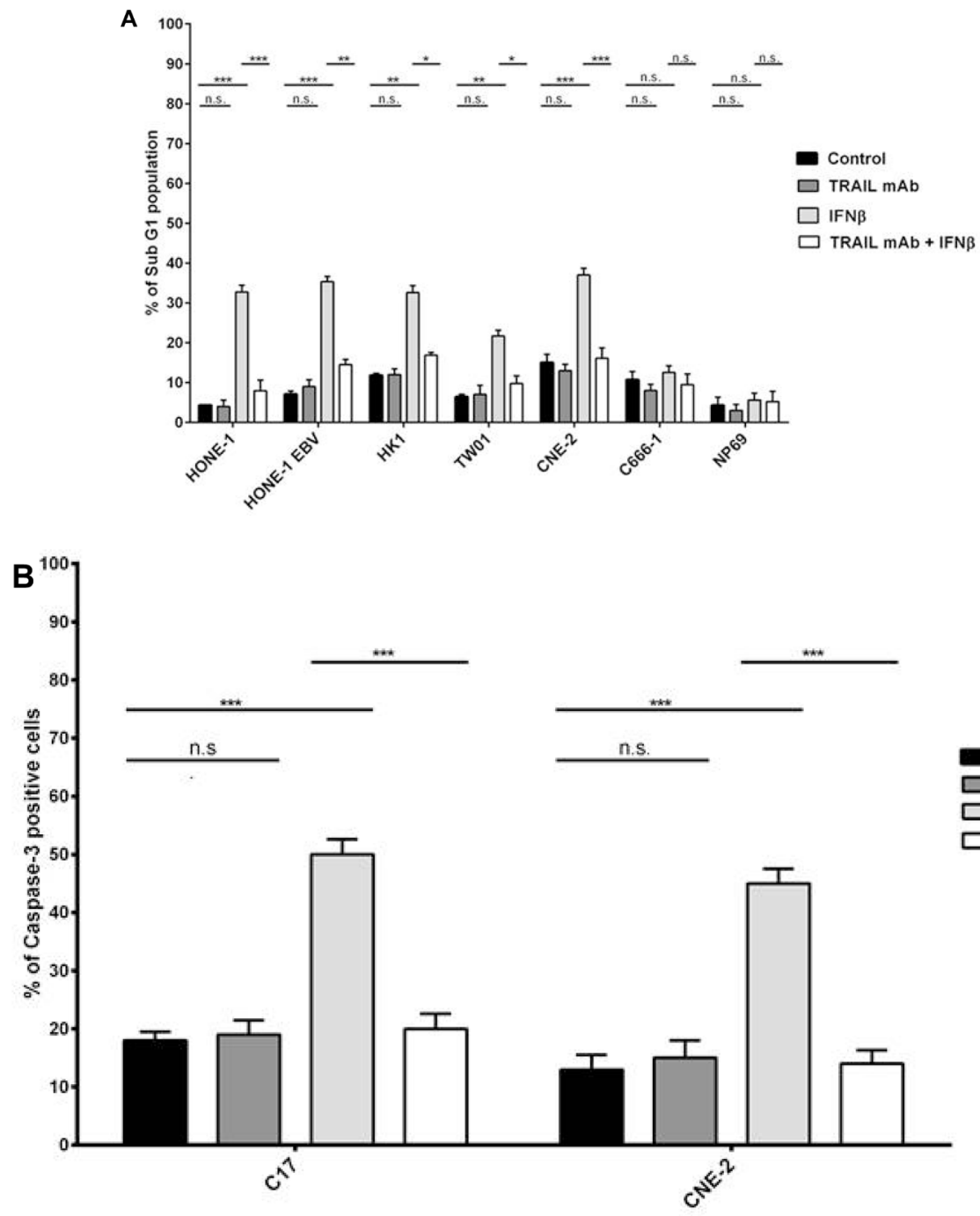

C IFN $\beta$ SCR SIRNA +
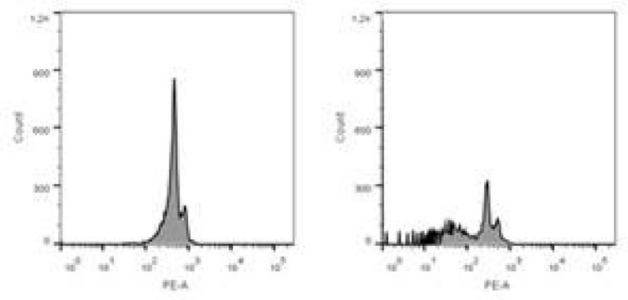

TRAIL SIRNA

IFN $\beta$
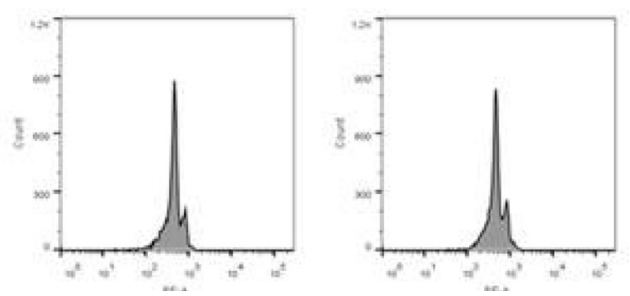


\section{D}
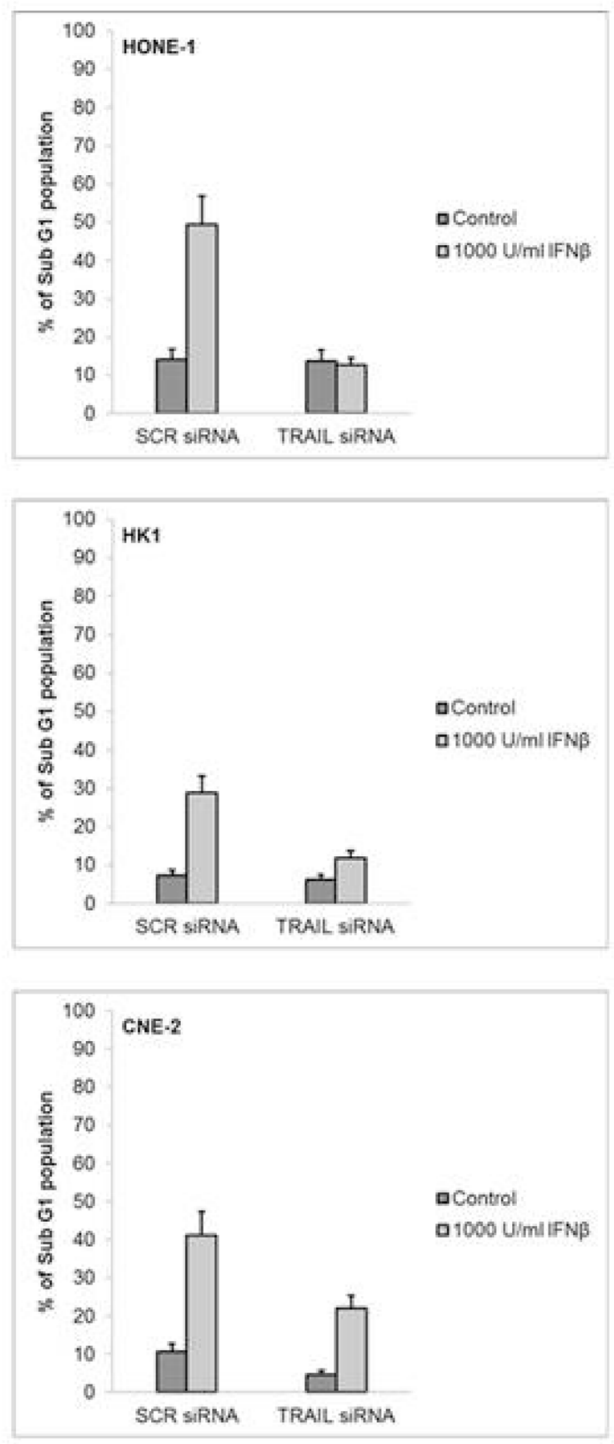
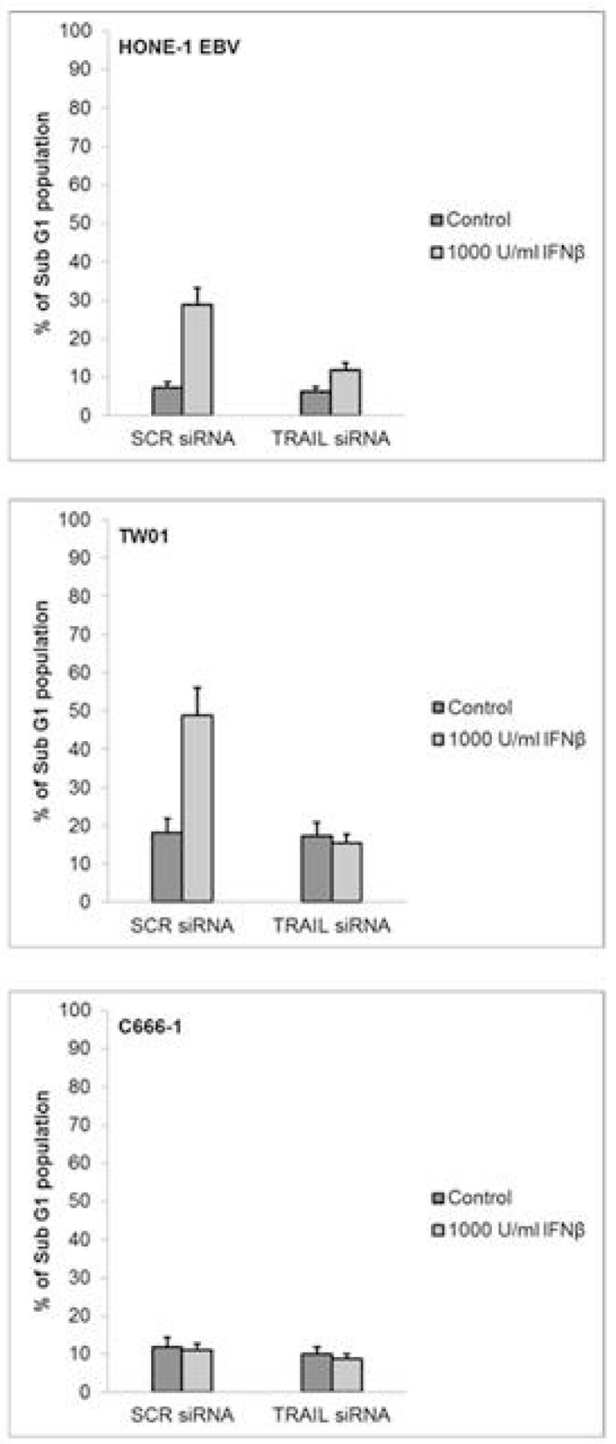

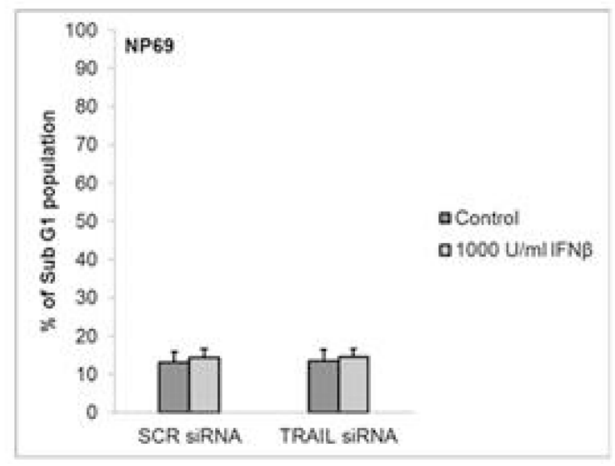

Figure 6: Inhibition of TRAIL inhibits IFN $\beta$-induced apoptosis in NPC cells. NPC cells were treated with 1,000 U/ml IFN $\beta$ for $72 \mathrm{~h}$ in the presence or absence of an anti-TRAIL blocking mAb; apoptosis was then measured by analysis of subG1-content (A) or detection of activated caspase-3 (B). Anti-TRAIL mAb inhibited IFN $\beta$-induced apoptosis in all IFN $\beta$-sensitive cell lines and C17-PDX cells. Quantitative data are reported as means \pm S.E.M. (triplicate samples). (C, D) Effect of siRNA knockdown of TRAIL on IFN $\beta$-induced apoptosis in NPC cells. Cells were transfected with TRAIL siRNA or scrambled (SCR) siRNA for $16 \mathrm{~h}$ and subsequently treated with 1,000 $\mathrm{U} / \mathrm{ml}$ IFN $\beta$ for $72 \mathrm{~h}$. Apoptosis was determined by flow cytometry of subG1-content. TW01 (C). Quantitative data analysis for all cell lines, reported as means \pm S.E.M. (triplicate samples) (D). 
were seeded into 96-well plates at a density of 2,500 cells/well within $200 \mu \mathrm{l}$ of growth medium. After $24 \mathrm{~h}$ of culture, cells were treated with different concentrations of IFN $\beta$ and incubated over defined time periods. At the end of the incubation periods $10 \mu \mathrm{l}$ of WST- 8 solution [2-(2-methoxy-4-nitrophenyl)-3-(4-nitrophenyl)-5-(2,4disulfophenyl)-2H-tetrazolium, monosodium salt] was added into each well. After $4 \mathrm{~h}$ the optical density (OD) of each well was measured at $450 \mathrm{~nm}$ with a microplate reader $($ viability $=($ ODtreat $/$ ODcontrol $) \times 100 \%)$.

\section{Cell cycle analysis}

Propidium-iodide staining of nuclei was used to determine the effect of IFN $\beta$ on cell cycle distribution as well as apoptosis by measurement of sub-G1 DNA content. NPC cells (about $70 \%$ confluent) were incubated with IFN $\beta$, FAS ligand, TRAIL or medium up to $72 \mathrm{~h}$. Cells were then trypsinized, centrifuged and cell pellets were suspended in $500 \mu \mathrm{l}$ fluorochrome solution containing $0.1 \%$ sodium citrate, $0.1 \%$ Triton $\mathrm{X}-100,50 \mathrm{mg} / 1$ propidium iodide in deionized/distilled water at a cell density of approximately $1 \times 10^{6} / \mathrm{ml}$ [48]. Samples were incubated about $1 \mathrm{~h}$ in the dark at $4^{\circ} \mathrm{C}$ and then measured by flow cytometry (BD FACS Canto II, San Jose, CA, USA); 10,000 cells per reaction were counted. Results were analyzed by the FlowJo software (FlowJo, Ashland, OR, USA). Three independent experiments were performed for each assay.

\section{Caspase-3 activity assay}

Caspase-3 activity was measured using a caspase-3 assay kit (BD Pharmingen, San Diego, USA) according to the manufacturer's instructions. Cells were treated with IFN $\beta$ (0-72 h), washed twice with cold PBS, lysed on ice in $1 \mathrm{ml}$ lysis buffer (Cytofix/Cytoperm ${ }^{\mathrm{TM}}$ Fixation and Permeabilization Solution) and further incubated for $20 \mathrm{~min}$ on ice. Cell lysates were then centrifuged at $1,000 \mathrm{rpm}$ for $5 \mathrm{~min}$. The pellet was washed twice with Perm/Wash ${ }^{\mathrm{TM}}$ Buffer and labeling performed by adding $100 \mu \mathrm{l}$ of washing buffer containing $20 \mu \mathrm{l}$ of antibody (BD Pharmingen). The samples were incubated for further $30 \mathrm{~min}$ at room temperature, washed in washing buffer and then analyzed by flow cytometry. A negative control sample incubated with FITC-immunoglobulin G was run in parallel. Three independent experiments were performed for each assay.

\section{Immunofluorescence staining of caspase-3}

Cells $\left(5 \times 10^{4}\right)$ were grown on coverslips and treated with TRAIL or FAS ligand for $24 \mathrm{~h}$. Cells then were washed and stained for active caspase- 3 protein according to the manufacturer's instructions (Caspase-3 assay kit; BD Pharmingen, San Diego, CA, USA). Fluorescent caspase-3 protein was immediately analyzed by fluorescence microscopy (AMG, Mill Creek, USA).

\section{Chromatin staining with Hoechst 33258}

Induction of apoptosis by IFN $\beta$ was also determined by Hoechst staining. Cells were seeded onto 6-well plates in culture medium, incubated at $37^{\circ} \mathrm{C}$ for $24 \mathrm{~h}$. The cells were then treated in culture medium with varying concentration of IFN $\beta(0-1,000 \mathrm{U} / \mathrm{ml})$ for $72 \mathrm{~h}$. At the end of the experiment, cells were detached from the plates by trypsinization and collected by centrifugation at 1,000 rpm for $5 \mathrm{~min}$ at room temperature. After washing with PBS, cells were stained with $300 \mu \mathrm{l}$ bis-benzimide (Hoechst 33258; $1 \mu \mathrm{g} / \mathrm{ml}$ in PBS) for $5 \mathrm{~min}$ at room temperature. The stained cells were then examined under a fluorescence microscope (AMG, Mill Creek, WA, USA) at $365 \mathrm{~nm}$ excitation. The numbers of normal and apoptotic nuclei in randomly selected areas were counted using a $20 \times$ objective. Phase contrast images were obtained to compare for cell density.

\section{Inhibition of apoptosis}

To identify the apoptotic pathways induced by IFN $\beta$, NPC cell lines were incubated with different caspaseinhibitors: pan-caspase-inhibitor Z-VAD-fmk (10 $\mu \mathrm{M})$, caspase-8-inhibitor Z-IETD-fmk $(10 \mu \mathrm{M})$ and caspase9-inhibitor Z-LEHD-fmk (10 $\mu \mathrm{M})$; also, the TRAILblocking antibody anti-TRAIL mAb $(100 \mathrm{ng} / \mathrm{ml})$ and the FAS-blocking antibody anti-ZB4 mAb (100 ng/ml) were used. Inhibitors were added at the indicated concentrations $1 \mathrm{~h}$ prior to the addition of $\operatorname{IFN} \beta(1,000 \mathrm{U} / \mathrm{ml})$. Apoptosis was determined via flow cytometry by the propidium-iodide method [28]. Results were analyzed by the FlowJo software (FlowJo). Three independent experiments were performed for each assay.

\section{Flow cytometric analysis of death ligand and their receptors}

NPC cells untreated or treated as above with IFN $\beta$ for the indicated time periods were suspended at a density of $1 \times 10^{6}$ cells in $500 \mu 1$ of medium and incubated with $5 \mu 1$ of mouse anti-human TRAIL-R1-, TRAIL-R2-, FAS- and TRAIL-antibody for $1 \mathrm{~h}$ on ice. After washing in PBS three times (5 min each), APC-conjugated goat-antimouse antibody (1:200) was added to the cell suspensions and incubated for $1 \mathrm{~h}$ on ice. Subsequent to rinsing in PBS, samples were analyzed by flow cytometry. Data were analyzed by the FlowJo software (FlowJo). Three independent experiments were performed for each assay.

\section{Confocal microscopy analysis of TRAIL expression}

NPC cells $\left(7.5 \times 10^{4}\right)$ were plated overnight on glass chamber slides (Thermo Fisher Scientific), followed by incubation with IFN $\beta(1,000 \mathrm{U} / \mathrm{ml})$ for $72 \mathrm{~h}$. Cells were then fixed with $4 \%$ paraformaldehyde, incubated 
with a monoclonal antibody recognizing TRAIL (Alexis Biochemicals, San Diego, CA, USA; 1:200) for $60 \mathrm{~min}$ in PBS containing $0.1 \%$ Tween 20 and $5 \mathrm{mg} / \mathrm{ml} \mathrm{BSA} \mathrm{(PBST/}$ BSA) followed by 30 min incubation with Alexa Fluor ${ }^{\mathrm{TM}}$ 488-conjugated anti-mouse IgG (Invitrogen, Carlsbad, CA, USA; 1:200 in PBST/BSA). Nuclei were stained with Hoechst 33258 as described above. In all cases, imaging was performed with a Zeiss LSM 510 laser scanning confocal/Confocor 2 microscope using a 40x DIC oil immersion objective and LSM 510 software; acquired images were imported into ImageJ (National Institute of Health; http://rsbweb.nih.gov/ij/).

\section{Immunoblot}

Immunoblotting was performed as described before [47]. Briefly, cells were washed and lysed in buffer containing $50 \mathrm{mM}$ Tris- $\mathrm{HCl}(\mathrm{pH} 7.4), 1 \%$ NP40, 0.5\% Na-deoxycholate, $0.1 \%$ SDS, $150 \mathrm{mM} \mathrm{NaCl}, 2$ $\mathrm{mM}$ EDTA, $50 \mathrm{mM} \mathrm{NaF}$ and protease and phosphatase inhibitors. Cellular proteins from total cell lysates (20 $\mu \mathrm{g} /$ sample) were separated by sodium dodecyl sulfatepolyacrylamide gel electrophoresis and transferred onto a nitrocellulose membrane. The membranes were probed using immunoblot analyses with $\mathrm{mAb}$ to human caspase-3 (1:1,000), caspase-8 (1:500) and Apo2L/TRAIL $(1: 1,000)$, followed by incubation with the goat antirabbit IgG-antibody for $1 \mathrm{~h}$ at room temperature. Equal protein loading was confirmed by reprobing filters with a monoclonal antibody against $\beta$-actin. Immunoreactive bands were detected using enhanced chemiluminescence and visualized by autoradiography.

\section{Caspase-3/7 and 8 activity assay}

Caspase-3/7 and caspase- 8 activities were determined using the Caspase-Glo 8 and the Caspase-Glo 3/7 assay kits (Promega, Madison, WI, USA) according to manufacturer's instructions. The assay is based on the cleavage of Z-DEVD-amino-luciferin (Caspase Glo 3/7) or Z-LETD-amino-luciferin (Caspase-Glo 8) by activated caspases-3/7 or -8 , respectively, and subsequent generation of a luminescent signal by luciferase. Briefly, NPC cells were seeded at a density of $1.5 \times 10^{4}$ cells per well in a 96-well assay plate overnight. IFN $\beta$ was then added for 3, 6, 9, 12, 24, 48 and $72 \mathrm{~h}$. At the end of the experiment, the respective Caspase-Glo reagent was added to each well at a ratio of 1:1 with cell culture media and samples were incubated with gentle agitation for $1 \mathrm{~h}$ at room temperature, protected from light. Luminescence of samples was then measured by a luminescence reader (TECAN Infinite 200 Pro, Tecan, Männedorf, Switzerland). Caspase activation was normalized to positive samples treated with recombinant caspase enzyme by dividing the raw luminescence units (RLUs) of IFN $\beta$ samples by the RLU value of positive controls $\times 100 \%$.

\section{Immunohistochemistry}

For immunohistochemical staining, $3 \mu \mathrm{m}$ sections of formalin fixed, paraffin-embedded tissue samples were deparaffinized by xylene and rehydrated by decreasing concentrations of ethanol. After heat-induced antigen retrieval by pH6 EDTA buffer (DAKO, Carpinteria, CA, USA), endogenous peroxidase activity was deactivated by $3 \%$ hydrogen peroxide. Nonspecific protein binding sites were blocked by Protein Block (DAKO, Carpinteria, CA, USA). Mouse anti-human TRAIL-R1 monoclonal antibody (Enzo Life Science, Clone TR1.02), mouse anti-human TRAIL-R2 monoclonal antibody (Enzo Life Science, Clone DJR2-2) and mouse anti-human TRAIL monoclonal antibody (R\&D System, Clone 75402) as well as mouse anti-pan-Keratin and anti-CD8 antibody (DAKO) were incubated with the slides for $60 \mathrm{~min}$. For detection, the polymere-based Envision Kit by DAKO (Carpinteria, CA, USA) was applied, including a secondary antibody and DAB (diaminobenzidine) for staining. After counterstain by hematoxylin, dehydration and coverslipping, stained sections were evaluated and histological photographs were taken using a Zeiss microscope (Zeiss, Oberkochen, Germany) and Olympus camera and analysis software (Olympus, Hamburg, Germany).

\section{Transfection of siRNA}

NPC cells were seeded at $10^{5}$ cells/well in 24-well plates. The following day, when cells reached about $80 \%$ confluency, culture medium was aspirated, cells washed with PBS, followed by transfection with Lipofectamine (Invitrogen, Carlsbad, CA, USA) of siRNA against TRAIL or scrambled siRNA. After $16 \mathrm{~h}$ the transfection mix was replaced with normal growth medium and the cells were treated with 1,000 U/ml IFN $\beta$ for indicated time periods. Transfection efficiency was monitored with measuring surface expression of TRAIL by flow cytometry. Three independent experiments were performed for each assay.

\section{Statistical analysis}

Experimental results were reported as a mean of at least three independent experiments conducted in quintuplicates for cell viability assays and triplicates for flow cytometric analyses. Data in bar graphs were represented as mean \pm S.E. Student's $t$-test was used to compared two sets of data with $p<0.05$ as statistically significant.

\section{Abbreviations}

NPC: nasopharyngeal carcinoma; EBV: EpsteinBarr virus; IFN $\beta$ : interferon beta; TRAIL: Tumor Necrosis Factor-Related Apoptosis Inducing Ligand; FASLG: Fas ligand; PDX: patient-derived xenograft. 


\section{Author contributions}

AM, LW, TB, NK, CV, PB, BD: performed the experiments; AM, UK: designed the experiments; AM, UK: wrote the paper. All authors read and approved the final manuscript.

\section{ACKNOWLEDGMENTS}

The authors thank Stefan Dreschers for technical support.

\section{CONFLICTS OF INTEREST}

The authors declare that they have no conflicts of interest.

\section{FUNDING}

The study has been funded internally by the Medical Faculty, RWTH University Aachen.

\section{REFERENCES}

1. Chua ML, Wee JT, Hui EP, Chan AT. Nasopharyngeal carcinoma. Lancet. 2016; 387:1012-24.

2. Raab-Traub N. Epstein-Barr virus in the pathogenesis of NPC. Semin Cancer Biol. 2002; 12:431-441.

3. Brennan B. Nasopharyngeal carcinoma. Orphanet J Rare Dis. 2006; 1:23.

4. Rodriguez-Galindo C, Wofford M, Castleberry RP, Swanson GP, London WB, Fontanesi J, Pappo AS, Douglass EC. Preradiation chemotherapy with methotrexate, cisplatin, 5-fluorouracil, and leucovorin for pediatric nasopharyngeal carcinoma. Cancer. 2005; 103:850-857.

5. Mertens R, Granzen B, Lassay L, Bucsky P, Hundgen M, Stetter G, Heimann G, Weiss C, Hess CF, Gademann G. Treatment of nasopharyngeal carcinoma in children and adolescents: definitive results of a multicenter study (NPC91-GPOH). Cancer. 2005; 104:1083-89.

6. Buehrlen M, Zwaan CM, Granzen B, Lassay L, Deutz P, Vorwerk P, Staatz G, Gademann G, Christiansen H, Oldenburger F, Tamm M, Mertens R. Multimodal treatment, including interferon beta, of nasopharyngeal carcinoma in children and young adults: preliminary results from the prospective, multicenter study NPC-2003-GPOH/DCOG. Cancer. 2012; 118:4892-4900.

7. Casanova M, Bisogno G, Gandola L, Cecchetto G, Di Cataldo A, Basso E, Indolfi P, D’Angelo P, Favini F, Collini P, Potepan P, Ferrari A, and Rare Tumors in Pediatric Age Group. A prospective protocol for nasopharyngeal carcinoma in children and adolescents: the Italian Rare Tumors in Pediatric Age (TREP) project. Cancer. 2012; 118:2718-2725.
8. Baujat B, Audry H, Bourhis J, Chan AT, Onat H, Chua DT, Kwong DL, Al-Sarraf M, Chi KH, Hareyama M, Leung SF, Thephamongkhol K, Pignon JP, and MAC-NPC Collaborative Group. Chemotherapy as an adjunct to radiotherapy in locally advanced nasopharyngeal carcinoma. Cochrane Database Syst Rev. 2006; 4:CD004329.

9. Kontny U, Franzen S, Behrends U, Bührlen M, Christiansen H, Delecluse H, Eble M, Feuchtinger T, Gademann G, Granzen B, Kratz CP, Lassay L, Leuschner I, et al. Diagnosis and Treatment of Nasopharyngeal Carcinoma in Children and Adolescents - Recommendations of the GPOH-NPC Study Group. Klin Padiatr. 2016; 228: 105-12.

10. Treuner J, Niethammer D, Dannecker G, Hagmann R, Neef V, Hofschneider PH. Successful treatment of nasopharyngeal carcinoma with interferon. Lancet. 1980; 1:817-18.

11. Wolff HA, Rödel RM, Gunawan B, Overbeck T, Herrmann MK, Hennies S, Hille A, Vorwerk H, Matthias C, Hess $\mathrm{CF}$, Christiansen H. Nasopharyngeal carcinoma in adults: treatment results after long-term follow-up with special reference to adjuvant interferon-beta in undifferentiated carcinomas. J Cancer Res Clin Oncol. 2010; 136:89-97.

12. Parker BS, Rautela J, Hertzog PJ. Antitumour actions of interferons: implications for cancer therapy. Nat Rev Cancer. 2016; 16:131-144.

13. Oliver BJ, Kohli E, Kasper LH. Interferon therapy in relapsing-remitting multiple sclerosis: a systematic review and meta-analysis of the comparative trials. J Neurol Sci. 2011; 302:96-105.

14. Lipton JH, Khoroshko N, Golenkov A, Abdulkadyrov K, Nair K, Raghunadharao D, Brummendorf T, Yoo K, Bergstrom B, and Pegasys CML Study Group. Phase II, randomized, multicenter, comparative study of peginterferon- $\alpha-2 \mathrm{a}$ (40 kD) (Pegasys) versus interferon $\alpha-2 \mathrm{a}$ (Roferon-A) in patients with treatmentnaïve, chronic-phase chronic myelogenous leukemia. Leuk Lymphoma. 2007; 48:497-505.

15. Kawano Y, Takahashi W, Eto M, Kamba T, Miyake H, Fujisawa M, Kamai T, Uemura H, Tsukamoto T, Azuma H, Matsubara A, Nishimura K, Nakamura T, et al. Prognosis of metastatic renal cell carcinoma with first-line interferon- $\alpha$ therapy in the era of molecular-targeted therapy. Cancer Sci. 2016; 107:1013-1017.

16. Mocellin S, Pasquali S, Rossi CR, Nitti D. Interferon alpha adjuvant therapy in patients with high-risk melanoma: a systematic review and meta-analysis. J Natl Cancer Inst. 2010; 102:493-501.

17. Bekisz J, Sato Y, Johnson C, Husain SR, Puri RK, Zoon KC. Immunomodulatory Effects of Interferons in Malignancies. J Interf Cytokine Res. 2013; 33:154-161.

18. Dedoni S, Olianas MC, Onali P. Interferon- $\beta$ induces apoptosis in human SH-SY5Y neuroblastoma cells through activation of JAK-STAT signaling and down-regulation of PI3K/Akt pathway. J Neurochem. 2010; 115:1421-1433.

19. Chawla-Sarkar M, Leaman DW, Borden EC. Preferential induction of apoptosis by interferon (IFN)-beta compared 
with IFN-alpha2: correlation with TRAIL/Apo2L induction in melanoma cell lines. Clin Cancer Res. 2001; 7:1821-1831.

20. Bernardo AR, Cosgaya JM, Aranda A, Jiménez-Lara AM. Synergy between RA and TLR3 promotes type I IFN-dependent apoptosis through upregulation of TRAIL pathway in breast cancer cells. Cell Death Dis. 2013; 4:e479.

21. Dittmer DP, Hilscher CJ, Gulley ML, Yang EV, Chen M, Glaser R. Multiple pathways for Epstein-Barr virus episome loss from nasopharyngeal carcinoma. Int J Cancer. 2008; 123:2105-2112.

22. Hidalgo M, Amant F, Biankin AV, Budinská E, Byrne AT, Caldas C, Clarke RB, de Jong S, Jonkers J, Mælandsmo GM, Roman-Roman S, Seoane J, Trusolino L, Villanueva A. Patient-derived xenograft models: an emerging platform for translational cancer research. Cancer Discov. 2014; 4:998-1013.

23. Gressette $M$, Vérillaud $B$, Jimenez-Pailhès AS, Lelièvre $H$, Lo KW, Ferrand FR, Gattolliat CH, Jacquet-Bescond A, Kraus-Berthier L, Depil S, Busson P. Treatment of nasopharyngeal carcinoma cells with the histonedeacetylase inhibitor abexinostat: cooperative effects with cisplatin and radiotherapy on patient-derived xenografts. PLoS One. 2014; 9:e91325.

24. Buchwalder PA, Buclin T, Trinchard I, Munafo A, Biollaz J. Pharmacokinetics and pharmacodynamics of IFN-beta 1a in healthy volunteers. J Interferon Cytokine Res. 2000; 20:857-866.

25. Borner C, Monney L. Apoptosis without caspases: an inefficient molecular guillotine? Cell Death Differ. 1999; 6:497-507.

26. Ichim G, Tait SWG. A fate worse than death: apoptosis as an oncogenic process. Nat Rev Cancer. 2016; 16:539-548.

27. Fulda S. Caspase- 8 in cancer biology and therapy. Cancer Lett. 2009; 281:128-133.

28. Wang W, Li J, Wen Q, Luo J, Chu S, Chen L, Qing Z, Xie G, Xu L, Alnemah MM, Li M, Fan S, Zhang H. 4EGI-1 induces apoptosis and enhances radiotherapy sensitivity in nasopharyngeal carcinoma cells via DR5 induction on 4E-BP1 dephosphorylation. Oncotarget. 2016; 7:2172821741. https://doi.org/10.18632/oncotarget.7824.

29. Apelbaum A, Yarden G, Warszawski S, Harari D, Schreiber G. Type I interferons induce apoptosis by balancing cFLIP and caspase- 8 independent of death ligands. Mol Cell Biol. 2013; 33:800-814.

30. Kayagaki N, Yamaguchi N, Nakayama M, Eto H, Okumura K, Yagita H. Type I interferons (IFNs) regulate tumor necrosis factor-related apoptosis-inducing ligand (TRAIL) expression on human T cells: A novel mechanism for the antitumor effects of type I IFNs. J Exp Med. 1999; 189:1451-1460.

31. Sato K, Hida S, Takayanagi H, Yokochi T, Kayagaki N, Takeda K, Yagita H, Okumura K, Tanaka N, Taniguchi T, Ogasawara K. Antiviral response by natural killer cells through TRAIL gene induction by IFN-alpha/beta. Eur J Immunol. 2001; 31:3138-3146.

32. Millonig A, Rudzki D, Hölzl M, Ehling R, Gneiss C, Künz B, Berger T, Reindl M, Deisenhammer F. High-dose intravenous interferon beta in patients with neutralizing antibodies (HINABS): a pilot study. Mult Scler. 2009; 15:977-983.

33. Tecchio C, Huber V, Scapini P, Calzetti F, Margotto D, Todeschini G, Pilla L, Martinelli G, Pizzolo G, Rivoltini L, Cassatella MA. IFNalpha-stimulated neutrophils and monocytes release a soluble form of TNF-related apoptosisinducing ligand (TRAIL/Apo-2 ligand) displaying apoptotic activity on leukemic cells. Blood. 2004; 103:3837-3844.

34. Borden EC, Jacobs B, Hollovary E, Rybicki L, Elson P, Olencki T, Triozzi P. Gene regulatory and clinical effects of interferon $\beta$ in patients with metastatic melanoma: a phase II trial. J Interferon Cytokine Res. 2011; 31:433-440.

35. Kirkwood JM, Ibrahim JG, Sosman JA, Sondak VK, Agarwala SS, Ernstoff MS, Rao U. High-Dose Interferon Alfa-2b Significantly Prolongs Relapse-Free and Overall Survival Compared With the GM2-KLH/QS-21 Vaccine in Patients With Resected Stage IIB-III Melanoma: Results of Intergroup Trial E1694/S9512/C509801. J Clin Oncol. 2001; 19:2370-2380.

36. Ascierto PA, Chiarion-Sileni V, Muggiano A, Mandalà M, Pimpinelli N, Del Vecchio M, Rinaldi G, Simeone E, Queirolo P. Interferon alpha for the adjuvant treatment of melanoma: review of international literature and practical recommendations from an expert panel on the use of interferon. J Chemother. 2014; 26:193-201.

37. Bidwell BN, Slaney CY, Withana NP, Forster S, Cao Y, Loi S, Andrews D, Mikeska T, Mangan NE, Samarajiwa SA, de Weerd NA, Gould J, Argani P, et al. Silencing of Irf7 pathways in breast cancer cells promotes bone metastasis through immune escape. Nat Med. 2012; 18:1224-1231.

38. Sizhong Z, Xiukung G, Yi Z. Cytogenetic studies on an epithelial cell line derived from poorly differentiated nasopharyngeal carcinoma. Int J Cancer. 1983; 31:587-90.

39. Zeng Y. Establishment of an epitheloid cell line and a fusiform cell line from a patient with nasopharyngeal carcinoma. Sci Sin. 1978; 21:127-134.

40. Glaser R, Zhang HY, Yao KT, Zhu HC, Wang FX, Li GY, Wen DS, Li YP. Two epithelial tumor cell lines (HNE-1 and HONE-1) latently infected with Epstein-Barr virus that were derived from nasopharyngeal carcinomas. Proc Natl Acad Sci USA. 1989; 86:9524-28.

41. Tsao SW, Wang X, Liu Y, Cheung YC, Feng H, Zheng Z, Wong N, Yuen PW, Lo AKF, Wong YC, Huang DP. Establishment of two immortalized nasopharyngeal epithelial cell lines using SV40 large T and HPV16E6/E7 viral oncogenes. Biochim Biophys Acta. 2002; 1590:150-158.

42. Cheung ST, Huang DP, Hui AB, Lo KW, Ko CW, Tsang YS, Wong N, Whitney BM, Lee JC. Nasopharyngeal carcinoma 
cell line (C666-1) consistently harbouring Epstein-Barr virus. Int J Cancer. 1999; 83:121-26.

43. Reid Y, Storts D, Riss T, Minor L. Authentication of Human Cell Lines by STR DNA Profiling Analysis. In: Assay Guidance Manual. Sittampalam GS, Coussens NP, Brimacombe K, Grossman A, Arkin M, Auld D, Austin C, Baell J, Bejcek B, Chung TDY, et al, editors. Assay Guidance Manual. (Bethesda MD, USA): Eli Lilly \& Company and the National Center for Advancing Translational Sciences; 2004.

44. Masters JR, Thomson JA, Daly-Burns B, Reid YA, Dirks WG, Packer P, Toji LH, Ohno T, Tanabe H, Arlett CF, Kelland LR, Harrison M, Virmani A, et al. Short tandem repeat profiling provides an international reference standard for human cell lines. Proc Natl Acad Sci USA. 2001; 98:8012-8017.
45. Tanabe H, Takada Y, Minegishi D, Kurematsu M, Masui T, Mizusawa H. Cell line individualization by STR multiplex system in the cell bank found cross-contamination between ECV304, and EJ-1/T24. Tissue Cult Res Commun. 1999; 18:329-338.

46. Chan SYY, Choy KW, Tsao SW, Tao Q, Tang T, Chung GTY, Lo KW. Authentication of nasopharyngeal carcinoma tumor lines. Int J Cancer. 2008; 122: 2169-2171.

47. Makowska A, Eble M, Prescher K, Hoß M, Kontny U. Chloroquine Sensitizes Nasopharyngeal Carcinoma Cells but Not Nasoepithelial Cells to Irradiation by Blocking Autophagy. PLoS One. 2016; 11:e0166766.

48. Riccardi C, Nicoletti I. Analysis of apoptosis by propidium iodide staining and flow cytometry. Nat Protoc. 2006; 1:1458-1461. 